\title{
ORIGINAL ARTICLE \\ New species records from Buton Island, South East Sulawesi, including regional range extensions
}

\author{
Melissa Donnelly ${ }^{1,2, *}$, Thomas E. Martin ${ }^{1}$, Olivia Cropper ${ }^{1,3}$, Ellena Yusti ${ }^{1}$, Arthur Arfian ${ }^{1}$, Rachael \\ Smethurst ${ }^{1}$, Catherine Fox ${ }^{1,4}$, Moira Pryde ${ }^{1,5}$, Hafirun ${ }^{6}$, Josh Phangurha ${ }^{1}$, Rianne N. van der Aar ${ }^{1}$, Amy \\ Hutchison $^{1,7}$, Ady Karya ${ }^{8}$, Kangkuso Analuddin ${ }^{8}$, Samsudin $^{1}$, Stephanie K. Courtney Jones ${ }^{9,10}$
}

\begin{abstract}
${ }^{1}$ Operation Wallacea Ltd, Wallace House Old Bolingbroke, Spilsby, Lincolnshire, PE23 4EX, UK

${ }^{2}$ Proyecto CUBABAT, Matanzas, 40100, Cuba

${ }^{3}$ Ove Arup \& Partners, Leeds, West Yorkshire, LS9 8EE, UK

${ }^{4}$ Long Beach City College, Long Beach, CA 90808, USA

${ }^{5}$ Department of Conservation, Nelson,
\end{abstract} 7010, New Zealand

${ }^{6}$ Ministry of Environment \& Forestry Republic of Indonesia, Buton, 93754, SE Sulawesi, Indonesia

${ }^{7}$ Biologic Environmental Survey, 24-26 Wickham St, East Perth, Western Australia 6004, Australia

${ }^{8}$ Department of Biology and Biotechnology, Universitas Halu Oleo, South East Sulawesi, Indonesia

${ }^{9}$ Centre for Sustainable Ecosystem Solutions, School of Earth Atmospheric \& Life Sciences, University of Wollongong, Wollongong, NSW 2522, Australia

${ }^{10}$ Division of Ecology and Evolution, Research School of Biology, The Australian National University, Canberra, ACT, 2600, Australia

*Corresponding author: proyectocubabat@gmail.com

DOI:https://doi.org/10.14709/ BarbJ.14.1.2021.03

Keywords: bat distribution, bat inventory, Buton Island, Chiroptera, cryptic, Indonesia, new species records, South East Sulawesi, Wallacea

received: January, 25th 2021 accepted: April, 30th 2021

\begin{abstract}
Peninsular Malaysia is currently thought to host the highest biodiversity of Old World bats of any region, with 110 species recorded. However, the availability of literature to facilitate a similarly thorough species 'checklist' is not as readily available for other parts of Southeast Asia, including Sulawesi, Indonesia. Here we highlight 13 new species records from the long-term bat monitoring programme on Buton Island, South East Sulawesi, expanding on Patterson et al.'s (2017) previous inventory for this study area. One species (Hipposideros galeritus) is a new record for Sulawesi, and seven species (Cynopterus c.f. minutus, Rousettus celebensis, Megaderma spasma, Hipposideros c.f. ater, Myotis c.f. horsfieldii, Myotis c.f. moluccarum, and Myotis c.f. muricola) are new records for Buton Island. The remaining five species (Thoopterus nigrescens, Dobsonia exoleta, Acerodon celebensis, Mosia nigrescens, and Mops sarasinorum) have been previously reported from Buton but were missing from the prior site inventory. We also correct a probable mistaken species identification in the previous inventory (Cynopterus cf. titthaecheilus, now identified as Thoopterus nigrescens). This brings the total of confirmed species detected on Buton to 35, equating to $46.7 \%$ of all Sulawesi's known bat diversity in c. $3 \%$ of its land area. We highlight Buton as a key area for conserving the region's bat species.
\end{abstract}

\section{ABSTRAK}

Semenanjung Malaysia merupakan salah satu pusat keanekaragaman hayati kelelawar tertinggi di dunia saat ini, yaitu dengan catatan sejumlah 110 jenis kelelawar teridentifikasi. Namun demikian, ketersediaan literatur untuk menunjang proses identifikasi jenis kelelawar tidak mencakupi beberapa wilayah di Asia Tenggara, termasuk salah satunya di Sulawesi, Indonesia. Penelitian ini bertujuan untuk melanjutkan inventarisasi Patterson et al. (2017), dan ditemukan new record tambahan sebanyak 13 jenis kelelawar melalui pengamatan jangka panjang di Pulau Buton, Sulawesi Tenggara. Jenis Hipposideros galeritus merupakan new record untuk Sulawesi dan tujuh spesies lainnya (Cynopterus c.f. minutus, Rousettus celebensis, Megaderma spasma, Hipposideros c.f. ater, Myotis c.f. horsfieldii, Myotis c.f. moluccarum, dan Myotis c.f. muricola) merupakan new record di Pulau Buton. Lima spesies lainnya (Thoopterus nigrescens, Dobsonia exoleta, Acerodon celebensis, Mosia nigrescens, dan Mops sarasinorum) telah dilaporkan dari penelitian sebelumnya dari Pulau Buton, tetapi tidak ditemukan di kawasan penelitian pada inventarisasi awal. Kami juga mengoreksi adanya kemungkinan kekeliruan identifikasi spesies pada inventarisasi sebelumnya (Cynopterus cf. titthaecheilus, sekarang diidentifikasi sebagai Thoopterus nigrescens). Inventarisasi ini mencatat total sebanyak 35 spesies kelelawar di Pulau Buton, atau 46.7\% dari total keanekaragaman jenis kelelawar yang terdata di Sulawesi, dari hanya $3 \%$ inventarisasi yang dilakukan dari total luas daratannya. Dengan demikian, penelitian ini menekankan pentingnya Pulau Buton sebagai salah satu kawasan utama untuk upaya pelestarian spesies kelelawar. 


\section{INTRODUCTION}

Southeast Asia hosts over $25 \%$ of known bat species globally, with species richness across the region underestimated by as much as 50\% (Kingston 2013, Lim et al. 2017). Peninsular Malaysia is currently thought to host the highest biodiversity of Old World bats of any region, with 110 species recorded and further species discoveries expected (Lim et al. 2017, 2019). However, the availability of literature to facilitate a similarly thorough species 'checklist' is not as readily available for other parts of Southeast Asia, including Sulawesi, Indonesia. The lowland forests of Sulawesi, which lie within the Wallacean biodiversity hotspot (Myers et al. 2000, Myers 2003) support diverse and highly endemic vertebrate communities (Whitten et al. 2002). Sulawesi has a particularly high level of endemism in mammals, estimated at 43\% (Wiantoro et al. 2017). However, the ecosystems and their resident biodiversity remain poorly known (Telnov 2011, Rheindt et al. 2020). Significant knowledge gaps remain not only in terms of a complete inventory for bat species, but also in terms of their ecology and behaviour, including many species which have been recorded or inferred within the area but not further studied since. A literature review by Broto \& Mortelliti (2019) found that of 144 detected mammal species in Sulawesi, for 34 no further research has been published about their ecology or behaviour. Further, of those 34 understudied mammal species, 27 (79\%) of those are Chiropteran. These knowledge gaps highlight the lack of research focus on bat species in Sulawesi, despite their high diversity.

To address this shortfall, an extensive biodiversity monitoring programme on Buton Island (hereafter Buton), South East Sulawesi Province, has been running for over 20 years, run by Universitas Halu Oleo and Operation Wallacea (Martin et al. 2015). As South East Sulawesi's largest offshore island, Buton may have similar levels of species richness and endemism to the rest of the region, although this is yet to be confirmed. An initial inventory of 23 bat species detected by these surveys was previously published by Patterson et al. (2017). However, survey work on Buton has continued in more recent years, and several more species have been detected during this time, including new spatial range records for both the island and for Sulawesi as a whole. Here, we summarise those new records, along with a correction regarding a species identification presented in Patterson et al. (2017), updating the current knowledge of the bat community of Buton and the distribution of bats within the Sulawesi region in general.

\section{METHODS}

\section{Study area}

Bat surveys were conducted within three nature reserves (each constituting uninhabited lowland monsoonal forest) and a single village. Lambusango Wildlife Reserve (hereafter LWR) $\left(65,000\right.$ ha; $\left.5^{\circ} 10^{\prime}-5^{\circ} 24^{\prime} \mathrm{S}, 122^{\circ} 43^{\prime}-123^{\circ} 07^{\prime} \mathrm{E}\right)$ and Kakenauwe Nature Reserve (hereafter KNR) ( 810 ha; $5^{\circ} 15^{\prime} \mathrm{S}$, $122^{\circ} 50^{\prime} \mathrm{E}$ ) are situated in the south-centre of Buton. Buton Utara Nature Reserve (hereafter BUNR) $\left(98,600\right.$ ha; $4^{\circ} 36^{\prime} \mathrm{S}$, $123^{\circ} 05^{\prime} \mathrm{E}$ ) is located in the north of the island (Table 1; Fig.

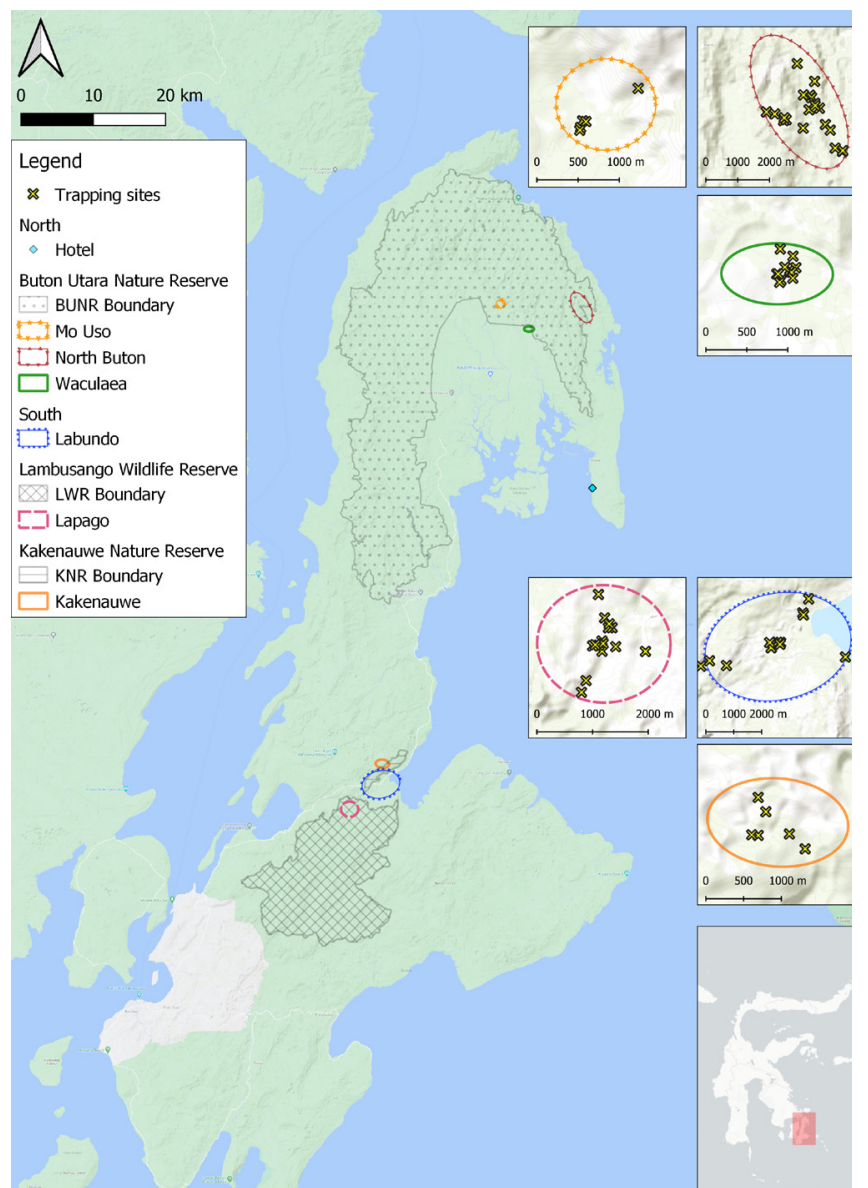

Fig. 1 - Survey localities across Buton Island, South East Sulawesi including Mo Uso (Orange with stars line), North Buton (Dark pink with triangles line), Waculaea (Solid green line) within Buton Utara Nature Reserve (BUNR); Lapago (Pink dashed line) within Lambusango Wildlife Reserve (LWR); Kakenauwe (Solid orange line) within Kakenauwe Nature Reserve (KNR); and Labundo-bundo and Linsowu (village; Blue with squares line). Insets indicate location of trapping sites within each survey locality. Map derived from Google Map, ESRI Topo, and Positron [no labels] (2021).

1) (Martin et al. 2015). The village of Labundo-bundo $\left(5^{\circ} 11^{\prime}\right.$ $\left.\mathrm{S}, 122^{\circ} 54^{\prime} \mathrm{E}\right)$, situated near the LWR, is a mix of farmland, mangrove, tropical lowland forest, coastal, and forest edge habitats (Martin et al. 2015). Any incidental observations outside those areas were also recorded (Table 1; Fig. 1). An occurrence dataset including acoustic recordings (Donelly et al. 2021) for all species will be made available on the Southeast Asian Bat Conservation Research Unit (SEABCRU) GBIF project page at the time of publication (https://doi. org/10.15468/qnz3rs). All new records presented here were detected during the 2018 Universitas Halu Oleo/ Operation Wallacea research season on Buton, running eight weeks between early June and early August.

\section{Bat trapping surveys}

Trapping sites were situated along established long-term biodiversity and habitat monitoring transects and adjacent habitats including forest, forest-edge, forest clearings, rivers, and farmland. Habitat types present in each study area are listed in Table 1. All trapping sites in each study area corresponded to one of these listed habitat types. Sites along transects were selected based on potential flyways (Kunz et al. 2009). Each site had between two to three nets and/or harp traps placed (Fig. 1). Sites were repeated 
only once a period of three nights had passed, to minimize disturbance to that area, or unless an earlier session was cancelled due to poor weather, in which case sites were sometimes repeated on consecutive nights (Hayes et al. 2009). Mist-nets and harp traps were placed perpendicular to trails and rivers and parallel to ridges. Mist-nets varied from 3, 6, 9, and $12 \mathrm{~m}$ in length and were placed within 50 $\mathrm{m}$ of one another. Mist-net hours were calculated based on $6 \mathrm{~m}$ nets with one $6 \mathrm{~m}$ equating to 1 hour, one $9 \mathrm{~m}$ equating to 1.5 hours, and one $12 \mathrm{~m}$ equating to 2 hours of trapping effort. Three to four-bank harp traps with a frame size of $2.4 \mathrm{~m}^{2}$, were placed within $100 \mathrm{~m}$ of one another. Harp trap hours were calculated based on one harp trap equating to 1 hour of trapping effort. In addition, we used Ecotone ultrathin monofilament nets (netting denier: $0.08 \mathrm{~mm}$, mesh size: $14 \times 14 \mathrm{~mm}$ ) to improve capture rate of insectivorous bats. Nets and harp traps were set up in forest, forest-edge, forest clearings, rivers, and farmland habitats between 17:00 and 24:00 each night and checked every 15 minutes and 30 minutes, respectively. A single Titley Scientific $7 \mathrm{~m}$ tall triple high system with three monofilament nets was employed in the same habitats. Additional targeted surveys were conducted in areas with potential to yield novel captures (e.g. abandoned buildings, caves and large hollow logs) and active searching of possible roosting sites (e.g. curled leaves and rocky overhangs).

Age, sex and reproductive status of all bats caught were recorded, along with the following morphometric measurements: weight ( $\mathrm{g}$; body mass taken using $50 \mathrm{~g}$, $100 \mathrm{~g}$, or $500 \mathrm{~g}$ Pesola spring scales depending on size of the bat), forearm length ( $\mathrm{mm}$; from the elbow to the carpus with wings folded), ear length ( $\mathrm{mm}$; measured from the base of the tragus or antitragus to the tip of the pinna), tragus length $(\mathrm{mm}$; from the notch on the outside of the tragus to the tip), tibia length ( $\mathrm{mm}$; measured from knee joint to ankle), hindfoot length ( $\mathrm{mm}$; measured from the heel to the longest digit, excluding hair and/or claws), tail length ( $\mathrm{mm}$; measured from base adjacent to the anus to tip of tail), head-body length ( $\mathrm{mm}$; from snout tip to the anus), and thumb ( $\mathrm{mm}$; measured from the maximum distance of the straight thumb, excluding wrist, hair and/or claws). For more detailed methodology refer to Dietz \& von Helversen (2004) and Srinivasulu et al. (2010).

Additional wing measurements for species undergoing taxonomic review were also measured: metacarpals II to V ( $\mathrm{mm}$; measured from the outer end of the carpus to the distal end of the metacarpal), third and fifth digits ( $\mathrm{mm}$; measured from the inside of the wrist to the tip of the finger), phalanx 1 of third finger ( $\mathrm{mm}$; measured from the distal end of metacarpal III to the distal end of first phalanx, Cynopterus $\mathrm{sp}$. only), phalanx 1 of fourth finger ( $\mathrm{mm}$; measured from the distal end of metacarpal IV to the distal end of first phalanx, Rhinolophus sp. only), and phalanx 2 of fourth finger ( $\mathrm{mm}$; measured from the distal end of phalanx 1 of fourth finger to the distal end of phalanx 2, Rhinolophus sp. only). For detailed methodology see Dietz \& von Helversen (2004). The forearm, tibia, hindfoot, thumb, metacarpals, phalanges and wing digits were measured using calipers to the nearest $0.1 \mathrm{~mm}$, while head-body length, tail length, ear, and tragus were measured using a $150 \mathrm{~mm}$ stainless steel ruler to the nearest $0.1 \mathrm{~mm}$. High-quality digital photographs of all captures were taken before releasing them. These photographs were incorporated into an open-access online Chicago Field Museum guide (Donnelly et al. 2020). No specimens or genetic samples were taken over the course of this fieldwork, as per permit regulations in Indonesian protected areas (Grajal 1999, Sodhi \& Liow 2000).

Captured bats were identified by using a field key and cross-referenced with data in the literature (Bergmans \& Rozendaal 1988, Flannery 1995, Bonaccorso 1998, Francis \& Hill 1998, Suyanto \& Kartikasari 2001, Payne \& Francis 2007, Huang et al. 2014, Phillipps \& Phillipps 2016, Wiantoro et al. 2017). Taxonomy followed Wilson \& Mittermeier (2019) and confirmed with https://batnames.org (Simmons \& Cirranello 2020). New species records were identified by comparing captures from this study with the species records in Patterson et al. (2017).

\section{Species conservation status and range extensions}

The conservation status of new species records were determined using the IUCN Red List (IUCN 2020). In addition, species endemic to the Wallacean biodiversity hotspot were noted (Myers et al. 2000). Two magnitudes of range extensions were considered (Patterson et al. 2017): major range extensions for species not previously reported from anywhere within the Sulawesi region, and minor range extensions for species known to occur on Sulawesi, but not indicated as occurring on Buton based on existing species distribution maps. Range extensions were identified by consulting each species distribution map in IUCN (2020), as well as records provided in published papers from the region or extralimital ranges (see Revilliod 1911, Bergmans \& Rozendaal 1988, Flannery 1995, Suyanto \& Kartikasari 2001, Riley 2002, Campbell et al. 2004, Maryanto et al. 2011, Wilson \& Mittermeier 2019).

\section{RESULTS}

A total of 950 individual bats comprising 32 species were captured or observed during 1,672 hours of trapping effort (235.4 harp hours over 26 nights and 1,437 net hours over 77 nights) across survey localities on Buton Island (Table 2; Fig. 3). Thirteen species were not previously reported in Patterson et al. (2017). Of these, one species is listed as Vulnerable and one species considered Data Deficient (IUCN 2020). We report one major range extension, seven minor range extensions and provide an annotated species inventory of new records for Buton (Fig. 2) including morphometric data for new species records (Table 3 \& 4), and photographic records of all species (Donnelly et al. 2020). As Indonesian bats remain understudied, additional measurements for the remainder of the species are provided (Table $5 \& 6$ ).

\section{Species accounts}

\section{Pteropodidae}

\section{Cynopterus c.f. minutus (Miller 1906)}

The Cynopterus species on Buton belong to the $C$. brachyotis complex, a cryptic group in need of genomic revision (Giannini et al. 2019). Three species from this 


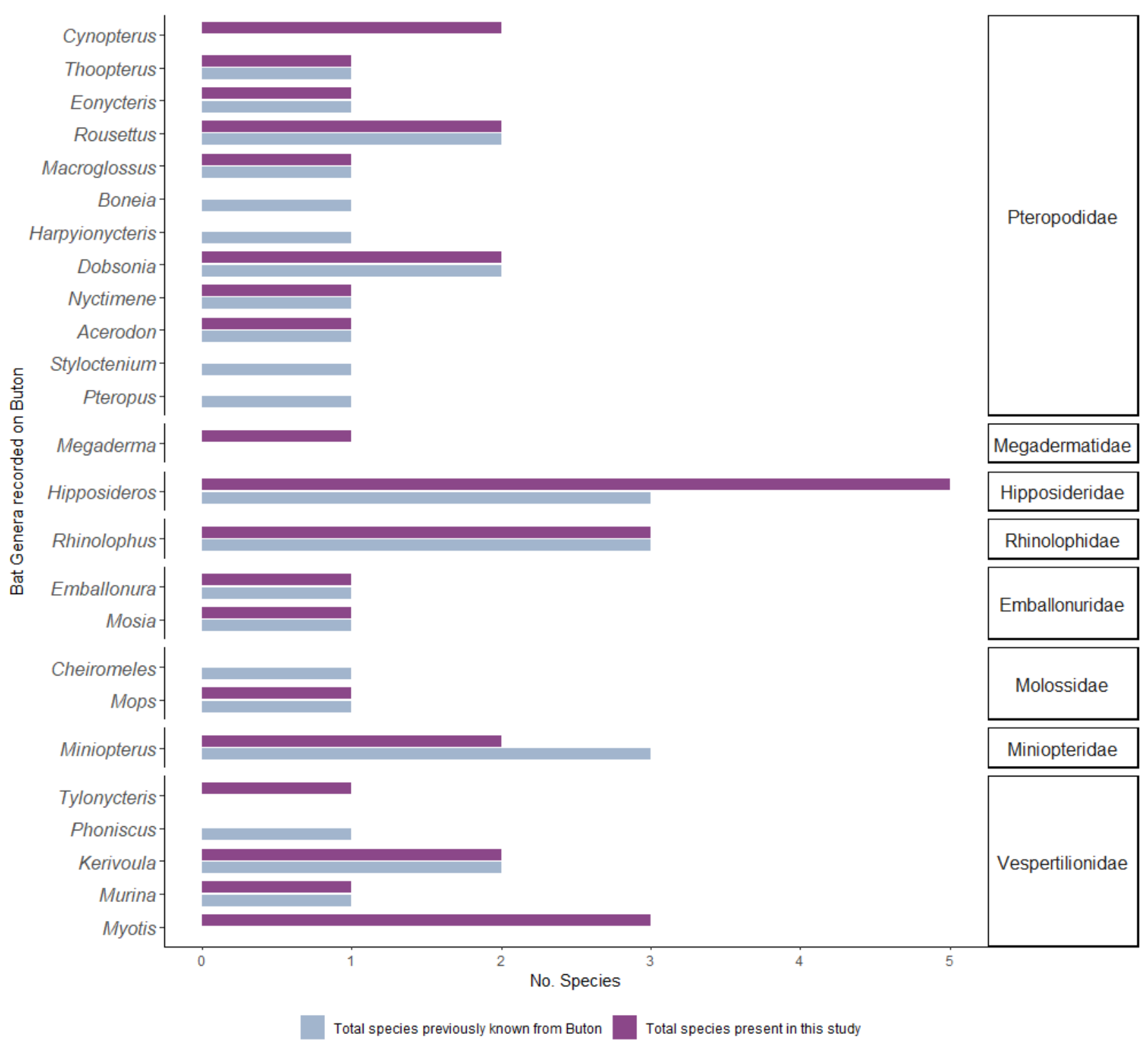

Fig. 2 - Number of bat species ( $\mathrm{X}$ axis) within each Genera ( $\mathrm{Y}$ axis) recorded during the 2018 sampling effort compared to what is known from Buton Island from previous studies.

complex are indicated to occur in Sulawesi (C. sphinx, C. Iuzoniensis and C. minutus) (Campbell et al. 2004, Rosell-Ambal et al. 2019) (Fig. 2). C. brachyotis does not occur on Sulawesi, with its eastern limits set to Borneo and Bali (Kitchener \& Maharadatunkamsi 1991). C. c.f. brachyotis referred by Patterson et al. (2017) likely refers to C. Iuzoniensis; however, C. Iuzoniensis from Sulawesi do not group with the originally described species from the Philippines and instead may represent $C$. minor, pending taxonomic recognition (Giannini et al. 2019). It may also be that future genetic analysis shows some Sulawesian Cynopterus populations to be new species (B. Lim pers. comms). As such, all members of this complex are denoted c.f. both here and in Patterson et al. (2017).

A total of 119 individual Cynopterus were captured in our survey work, constituting at least two species (Table 3 \& 5). It was not possible to assign a species to all individuals, although preliminary discriminant analyses suggest that the $2^{\text {nd }}$ metacarpal may differ between Cynopterus species on Buton (Donnelly unpublished data).
Individuals identified as C. minutus appear to have a longer $2^{\text {nd }}$ metacarpal measurement $(>30 \mathrm{~mm})$ than $C$. c.f. luzoniensis ( $<30 \mathrm{~mm}$ ) (Table $4 \& 6$ ), which may be an effective means of differentiating them. It is also possible that $C$. sphinx is present on Buton, as individuals with forearm measurements greater than $65 \mathrm{~mm}$ were caught. Given overlapping morphometrics, further genomic analyses are required.

A total of 21 individuals were assigned to $C$. c.f. minutus based on the length of the second metacarpal. These records would represent a minor range extension for the species, as it is known to occur on mainland South East Sulawesi, but not Buton (Ruedas \& Suyanto 2019). Captures were represented from both forest habitats and farmland close to forest edge at Labundo-bundo, Lapago, North Buton camp, and Waculaea study sites (Table 1 \& 2; Fig. 3A, 3B). Lactating and post-lactating individuals were caught throughout July. Males with engorged testes and orange mantles were captured throughout June and July. Individuals captured on Buton mostly fall within the morphometric ranges described for C. minutus in Wilson \& Mittermeier (2019) with the 
Melissa Donnelly, Thomas E. Martin, Olivia Cropper, Ellena Yusti, Arthur Arfian, Rachael Smethurst, Catherine Fox, Moira Pryde, Hafirun, Josh Phangurha, Rianne N. van der Aar, Amy Hutchison, Ady Karya, Kangkuso Analuddin, Samsudin, Stephanie K. Courtney Jones

Table 1 - Survey localities for trapping sites and observations of bats made on Buton Island, South East Sulawesi. Numbers in parentheses indicate the number of trapping sites used in study area. * single incidental capture at a location outside our focus area.

\begin{tabular}{|c|c|c|c|c|c|c|}
\hline $\begin{array}{l}\text { Study area } \\
\text { (trapping sites } \mathrm{n} \text { ) }\end{array}$ & Locality & Municipality & Latitude & Longitude & Elevation (m) & Habitat \\
\hline \multicolumn{7}{|l|}{ Village } \\
\hline $\begin{array}{l}\text { Labundo-bundo } \\
(n=13)\end{array}$ & Kakenauwe & Buton Regency & -5.1866 & 122.906817 & 35 & $\begin{array}{l}\text { Farmland (coconut } \\
\text { and bananas)/ } \\
\text { Limestone caves/ } \\
\text { Lowland forest edge/ } \\
\text { Coastal/ Mangrove }\end{array}$ \\
\hline $\begin{array}{l}\text { Linsowu } \\
(\mathrm{n}=1)^{*}\end{array}$ & Linsowu & Buton Regency & -4.8161 & 123.17332 & 10 & $\begin{array}{l}\text { Beach hotel/ Coastal/ } \\
\text { Lowland forest }\end{array}$ \\
\hline \multicolumn{7}{|c|}{ Lambusango Wildlife Reserve } \\
\hline $\begin{array}{l}\text { Lapago } \\
(n=19)\end{array}$ & Wakangka & Buton Regency & -5.2134 & 122.874333 & 234 & $\begin{array}{l}\text { Lowland forest/ } \\
\text { Limestone caves }\end{array}$ \\
\hline \multicolumn{7}{|c|}{ Kakenauwe Nature Reserve } \\
\hline $\begin{array}{l}\text { Kakenauwe } \\
(n=6)\end{array}$ & Waoleona & Buton Regency & -5.1624 & 122.912333 & 269 & $\begin{array}{l}\text { Lowland forest/ } \\
\text { Limestone caves/ } \\
\text { Remnant farmland }\end{array}$ \\
\hline \multicolumn{7}{|c|}{ Buton Utara Nature Reserve } \\
\hline $\begin{array}{l}\text { North Buton } \\
\text { camp } \\
(n=28)\end{array}$ & Lanosangia & North Buton Regency & -4.5892 & 123.63033 & 44 & $\begin{array}{l}\text { Lowland forest/ } \\
\text { Limestone caves/ } \\
\text { Farmland/ Recent } \\
\text { logging evident }\end{array}$ \\
\hline $\begin{array}{l}\text { Waculaea } \\
(n=11)\end{array}$ & Lanosangia & North Buton Regency & -4.6167 & 123.083667 & 96 & $\begin{array}{l}\text { Lowland forest/ } \\
\text { Farmland }\end{array}$ \\
\hline $\begin{array}{l}\text { Mo Uso } \\
(n=7)\end{array}$ & Tombia & North Buton Regency & -4.5884 & 123.055511 & 60 & $\begin{array}{l}\text { Lowland forest/ } \\
\text { Limestone caves/ } \\
\text { Areas of abandoned } \\
\text { logging }\end{array}$ \\
\hline
\end{tabular}

exception of the forearm reaching lengths greater than 60 $\mathrm{mm}$ (Table 3). Given the cryptic nature of Cynopterus, it is probable that individuals of $C$. c.f. minutus were indeed caught in the fieldwork of Patterson et al. (2017) but were grouped with C. c.f. brachyotis.

\section{Thoopterus nigrescens (Gray 1870)}

A Wallacean endemic indicated as occurring on Buton (Ruedas et al. 2008) and identified as Cynopterus c.f. titthaecheilus by Patterson et al. (2017).

Revision of the photographic records identifies the individuals caught by Patterson et al. (2017) as Thoopterus nigrescens. There are morphological similarities between the Cynopterus genus and Thoopterus. Thoopterus were originally described and grouped with Cynopterus (Grey 1870). Specifically, photo records provided in Patterson et al. (2017) show no white rim around the ears or white finger bones; diagnostic features of all Cynopterus species. Further, identification of these individuals as $T$. nigrescens match known spatial distributions, with $C$. titthaecheilus not being reported from the Sulawesi region (Tsang 2016). We recommend removing $C$. c.f. titthaecheilus from the overall inventory of Buton.
Individuals previously captured by Patterson et al. (2017) had brown-coloured fur, with long greyish-light brown dense fur on the ventral side, and black wings. They were quite muscular, with short muzzles and round robust heads, matching previous descriptions (Flannery 1995).

This species may be mistaken for Thoopterus suhaniahae which have longer forearms and wider calcar than T. nigrescens (Maryanto et al. 2012). Harpyionycteris celebensis may also be mistaken for T. nigrescens in the field as they overlap in all standard measurements but differ only in the shape of their muzzle, with Thoopterus having a broad short muzzle and Harpyionycteris being narrower and longer (Giannini et al. 2019). The presence of Thoopterus nigrescens on Buton has been previously confirmed by Maryanto et al. (2012).

\section{Rousettus celebensis (Andersen 1907)}

Currently, three Rousettus species are known to occur on Sulawesi ( $R$. amplexicaudatus, $R$. celebensis, and $R$. linduensis). At time of publication, Rousettus was identified as the incorrect genus for this species and belongs to the new genus Pilonycteris (Nesi et al. 2021). Future publications should therefore refer to this species as Pilonycteris celebensis (Nesi et al. 2021). A Wallacean endemic, $R$. celebensis on Buton is a minor range extension. 
Table 2 - Species summaries and trapping effort for each survey locality during the 2018 sampling period. * Species considered to have a minor range extension (previously reported from South East Sulawesi but not on Buton Island). ** Species considered to have a major range extension (not previously reported from Sulawesi). + Species assessed as threatened or near threatened by the IUCN (2020). $¥$ Species endemic to the Wallacean biodiversity hotspot as defined by Myers (2003). \# Species known only from photographic records, with no individuals caught.

Number of individuals captured per study area

\begin{tabular}{|c|c|c|c|c|c|c|c|c|}
\hline Family & Species & $\begin{array}{l}\text { 을 음 } \\
\text { 들 } \\
\text { 을 }\end{array}$ & 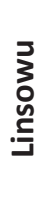 & 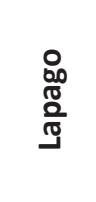 & 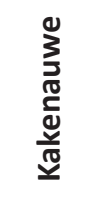 & 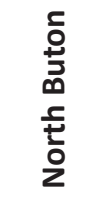 & 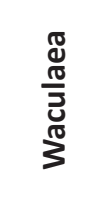 & $\begin{array}{l}0 \\
\stackrel{n}{2} \\
\text { ¿ }\end{array}$ \\
\hline \multirow{4}{*}{ Pteropodidae } & Cynopterus c.f. minutus* & 10 & & 3 & & 6 & 2 & \\
\hline & Rousettus celebensis $\ddagger^{*}$ & 6 & & 2 & & 11 & & \\
\hline & Dobsonia exoleta $\ddagger$ & 10 & & & & & & \\
\hline & Acerodon celebensis $\ddagger^{* \#}$ & & & & & & & 3 \\
\hline Megadermatidae & Megaderma spasma* & 10 & & 3 & 2 & 4 & & \\
\hline \multirow{2}{*}{ Hipposideridae } & Hipposideros galeritus** & 1 & & & & & & \\
\hline & Hipposideros c.f. ater & 1 & & & & & 2 & \\
\hline Emballonuridae & Mosia nigrescens & & & & & 1 & & \\
\hline \multirow[t]{2}{*}{ Molossidae } & Mops sarasinorum & 3 & & & & & & \\
\hline & Myotis c.f. horsfieldii* & & & & & & 19 & \\
\hline \multirow[t]{6}{*}{ Vespertilionidae } & Myotis c.f. moluccarum & 3 & 1 & & & & & \\
\hline & Myotis c.f. muricola* & & & & & 1 & 3 & \\
\hline & Total species & 20 & 1 & 12 & 6 & 17 & 11 & 8 \\
\hline & Total individuals & 138 & 1 & 65 & 32 & 375 & 220 & 133 \\
\hline & Net hours & 283.8 & 0 & 485.6 & 179.4 & 539.0 & 165.7 & 59.3 \\
\hline & Harp trap hours & 4.5 & 0 & 37.6 & 0.0 & 97.0 & 70.2 & 26.0 \\
\hline
\end{tabular}

A total of 15 individuals were captured throughout Labundo-bundo, Waculaea, North Buton camp and Lapago (Table 1 \& 2; Fig. 3C), making them a widespread, regularly encountered species. Males with engorged testes, orange shoulder patches and strong musky odour were captured from early June to early July, with lactating and post-lactating females captured late June to early July. The frequency of captures in this study suggests $R$. celebensis was possibly captured by Patterson et al. (2017) but misidentified as $R$. amplexicaudatus. The $R$. celebensis caught in this study were differentiated from $R$. amplexicaudatus by their smaller forearm length (Table 3), longer pelage, and furred tibia (which are naked in $R$. amplexicaudatus).

\section{Dobsonia exoleta (Andersen 1909)}

Hutson et al. (2019) indicated Dobsonia exoleta as potentially occurring on Buton according to genetic evidence. Our surveys confirmed the presence of two species of Dobsonia: D. exoleta and D. crenulata (reported in Patterson et al. 2017). Disentangling different species within Dobsonia remains challenging due to the overlap in standard measurements and ongoing taxonomic revision for the Sulawesi region, with most identifying features relying heavily on cranial and dental measurements (Flannery 1995). In this study, fur colour was used to differentiate species, with $D$. exoleta exhibiting bright yellow fur and
D. crenulata dull brown (Giannini et al. 2019). Given overlapping morphometrics, further genomic analyses are required.

Ten individuals were assigned to $D$. exoleta (Table $3 \&$ 4 ) and two to $D$. crenulata (Table $5 \& 6$ ). It is also possible that individuals previously identified as $D$. crenulata by Patterson et al. (2017) may in fact have been a mix of both $D$. crenulata and $D$. exoleta considering the high number of individuals of $D$. exoleta captured in the 2018 field season. Individuals were hand-netted from limestone caves located in both Labundo-bundo and Lapago (Table 1 \& 2; Fig. 3D). Males with engorged testes were captured along with three juveniles. No females showed signs of breeding.

\section{Acerodon celebensis (Peters 1867)}

A Wallacean endemic and a globally Vulnerable species previously mapped as occurring on Buton (Tsang \& Sheherazade 2016); however, not detected by Patterson et al. (2017). Three individuals were observed feeding on figs in a Ficus tree in Mo Uso (Table 1 \& 2; Fig. 3E). Anecdotal records also exist of $A$. celebensis in small groups observed in the vicinity of Labundo-bundo (F. Mantan pers. comms). Identification was based on the pigment of the wing membrane between the second and third digit being considerably lighter than the rest of the membrane. 


\section{Megadermatidae}

\section{Megaderma spasma (Linnaeus 1758)}

A geographically widespread species that is easily identified in the field by their long ears, biforked tragus, and woolly blue-grey fur. A minor range extension that has not been previously detected on Buton, however, is reported as occurring on mainland South East Sulawesi (Francis 2019, Srinivasulu et al. 2019).

A total of 15 individuals were recorded across all field sites except Mo Uso (Table 1 \& 2; Fig. 3F), from a range of habitats including farmland and closed canopy forest. Roosts found included derelict buildings, rotting logs and caves. Breeding males, post-lactating females and a single juvenile were captured mid-June to early July. Despite our fairly regular recording of this species, it was not reported by Patterson et al. (2017). This species is known to employ both active and passive echolocation for hunting and navigating, which can increase the likelihood of evading nets and harp traps (Wang \& Müller 2009). It may be that the sensitive echolocation and agility of $M$. spasma (being a gleaning species) prevented capture in the standard nets used previously (Patterson et al. 2017). The use of finer monofilament Ecotone nets (which $M$. spasma may find more difficult to avoid), along with targeted mist-netting and hand-netting in specific microhabitats where the species was suspected to occur (including roosts) may have increased detection in this study.

$\underline{\text { Hipposideridae }}$

\section{Hipposideros galeritus (Cantor 1846)}

This species has not been reported occurring east of Wallace's line (Srinivasulu \& Srinivasulu 2019, Wilson \& Mittermeier 2019, IUCN 2020). Bates et al. (2007) refer to $H$. galeritus specimens from Kakenauwe Forest Reserve on Buton despite this species not being reported elsewhere in the Sulawesi region. Our records on Buton corroborate Bates et al. (2007) and highlight the presence of $H$. galeritus on Buton. Captures of $H$. galeritus in this study thus represent a major range extension.

One individual was caught in farmland in close proximity to forest near Labundo-bundo (Table 1 \& 2; Fig. 3G). The individual had two supplementary leaflets. The tail was relatively long with five visible tail vertebrae, in comparison to those of $H$. cervinus which only had four vertebrae. The shape of the noseleaf also differed, with the intermediate noseleaf being wider than the posterior noseleaf. These descriptions are in line with $H$. galeritus described from other regions (Jenkins \& Hill 1981). This individual was caught in a harp trap and showed no sign of breeding.

\section{Hipposideros c.f. ater (Cantor 1846)}

A geographically widespread species found throughout South and South-east Asia. Currently there are seven subspecies recognized and the group is in need of taxonomic revision (Soisook et al. 2019). A minor range extension previously reported as occurring throughout mainland Sulawesi but not on Buton (Csorba et al. 2008).
Only three individuals (two males and one female) were caught during the sampling period in Labundobundo, Waculaea, and North Buton camp (Table 1 \& 2; Fig. $3 \mathrm{H}$ ). Only one male showed signs of breeding mid-July. Individuals caught did not have supplementary leaflets and the internarial septum was swollen in the middle. Fur was golden cream and white at the base. Our measurements and description fall in line with what is known for this species (Table 3), but currently there is great variation in the shape of the internarial septum amongst subspecies, suggesting that with further revision, cryptic species may arise (Soisook et al. 2019).

Emballonuridae

\section{Mosia nigrescens (Gray 1843)}

Previously indicated as occurring on Buton (Bonaccorso \& Leary 2008) but not reported in Patterson et al. (2017).

This species was recorded once, a single female adult showing no signs of reproduction, caught in a triple high mist-net system in closed canopy forest near limestone rocky overhangs in North Buton camp on 21/06/18 (Table 1 \& 2; Fig. 3I). Mosia are fast-flying aerial insectivores with large eyes (Bonaccorso 2019) like Megaderma spasma, making them difficult to capture via standardized survey techniques and therefore requiring more targeted survey efforts.

M. nigrescens differed from Emballonura monticola in its size and dirty blonde pelage, with forearm length being noticeably shorter (Table $3 \& 5$ ).

$\underline{\text { Molossidae }}$

\section{Mops sarasinorum (Lesson 1842)}

A Data Deficient species that may be conspecific with $M$. mops (Taylor et al. 2019). It has been previously indicated to occur on Buton (Rosell-Ambal et al. 2016) but not previously reported Patterson et al. (2017).

We recorded this species three times (Table 3), all captured in the triple high system near farmland while commuting over an open brackish river channel near Labundo-bundo (Table 1 \& 2; Fig. 3J). None showed any evidence of breeding. Individuals were vibrant chestnutorange in colouration. The tail extended beyond the edge of the uropatagium. The upper lip was wrinkled and there was a band of skin running across the top of the head, joining both ears with a tuft of fur in the middle on the underside. The anterior edge of the pinna was also lined with fur.

\section{$\underline{\text { Vespertilionidae }}$}

\section{Myotis c.f. horsfieldii (Temminck 1840)}

A widespread species found across South and South-east Asia, including Sulawesi (Phelps et al. 2019). The presence of these individuals on Buton indicates a minor range extension.

Twenty-four individuals were captured within riparian habitat in both mist-nets and harp traps placed at North Buton camp and Waculaea (Table 1 \& 2; Fig. 3K). Only males showed signs of breeding, with enlarged testes. 
A
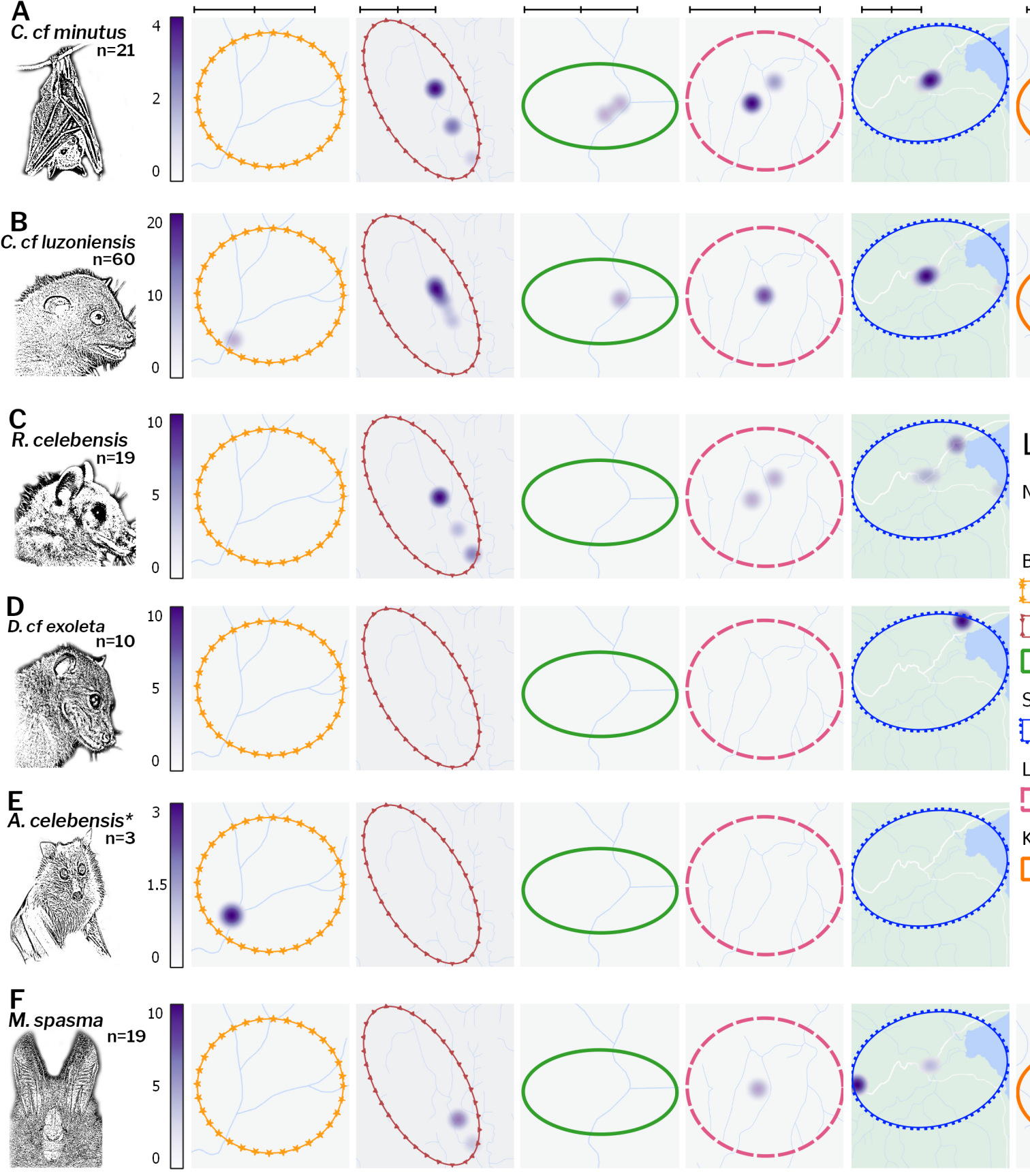

Legend North $\diamond$ Hotel

BUNR Mo Uso

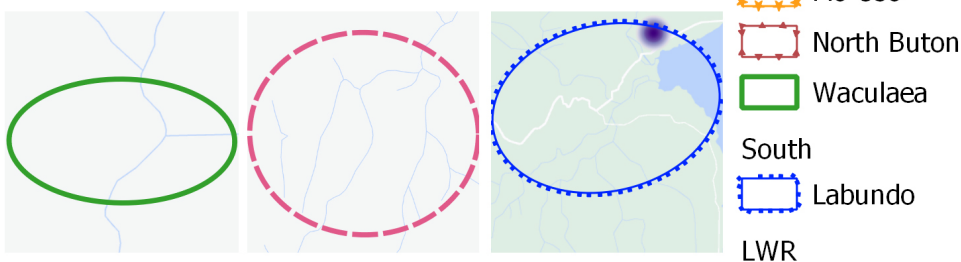

LWR T-I Lapago KNR

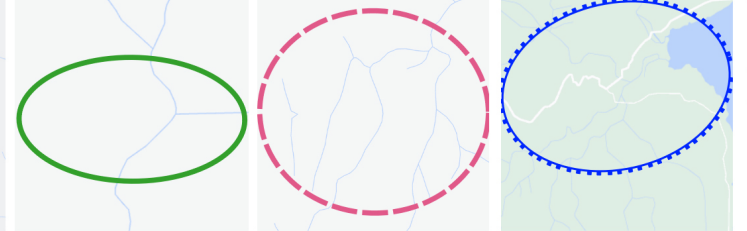

Kakenauwe
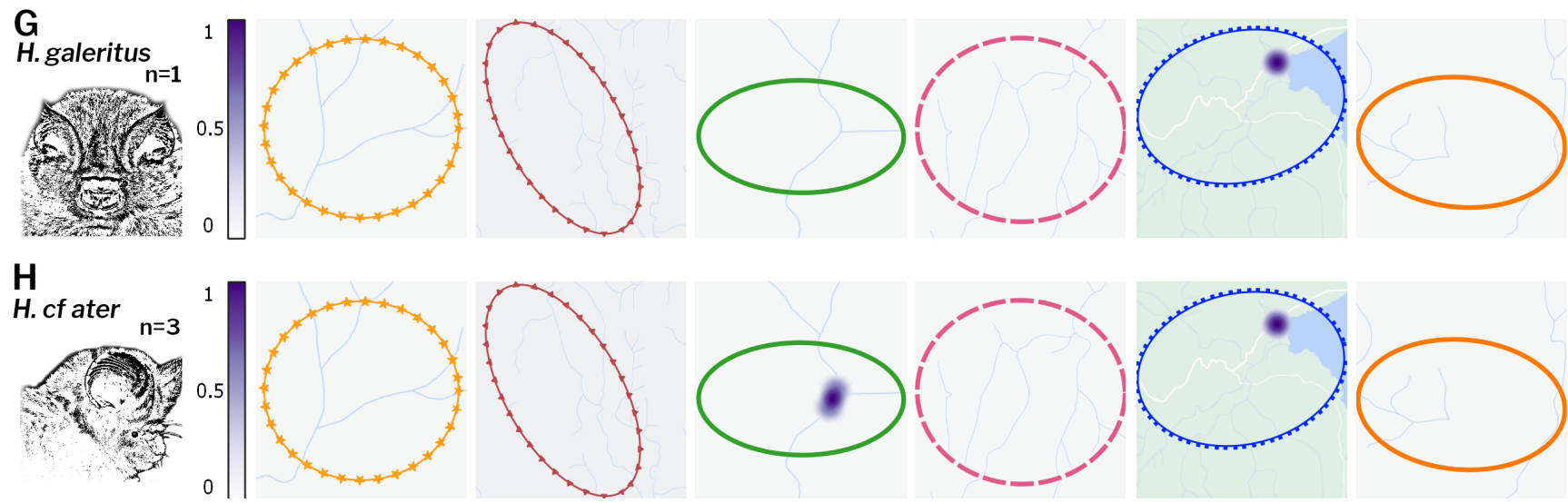

Fig. 3 - The distribution of trapping and observations of new bat species records on Buton Island, South East Sulawesi. The number of individuals for new species (species names and total number of captures/observations provided on Y axis) were counted at each trapping site located within survey localities (see Fig. 1 for survey localities on Buton Island). Depth of colour is proportional to the number of individuals captured for each species at each trapping site and with detail listed in Table 2. Lines indicate survey locality boundaries (see Fig. 1 for further detail). Scale bars differ between columns. Map derived from Google Maps (2021). * Denotes photos provided by Sarah Curran. 


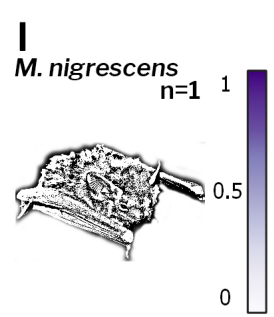

$\begin{array}{lllll}0 & 500 \quad 1000 \mathrm{~m} \quad 0 \quad 10002000 \mathrm{~m}\end{array}$

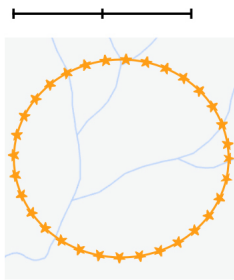

J

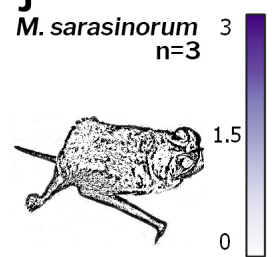

K

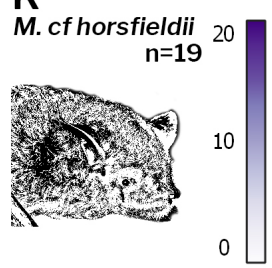

L
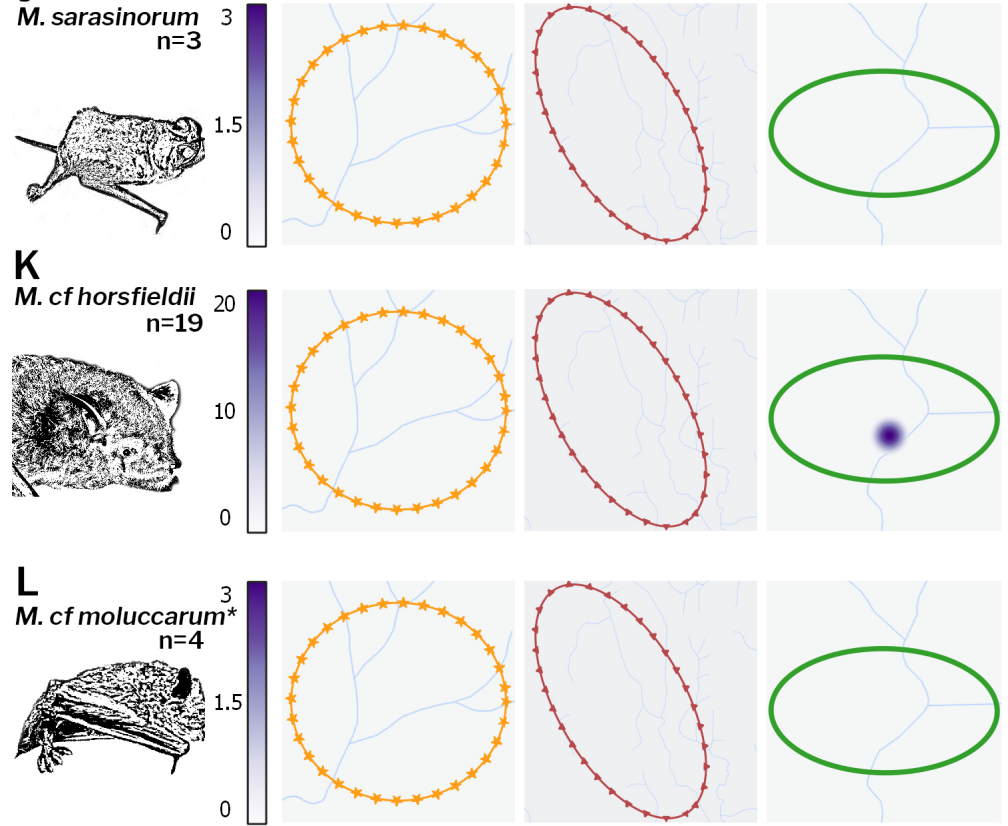

$0 \quad 500 \quad 1000 \mathrm{~m} \quad 0$
0

$1000 \quad 2000 \mathrm{~m} 010002000 \mathrm{~m}$
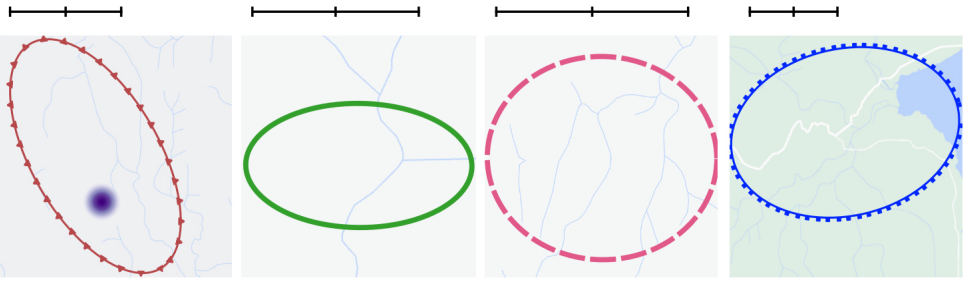

Legend

North

$\diamond$ Hotel

BUNR

*** Mo Uso

$\rightarrow$ M North Buton

L. North Buton

Waculaea

South

Labundo

LWR

Г- Lapago
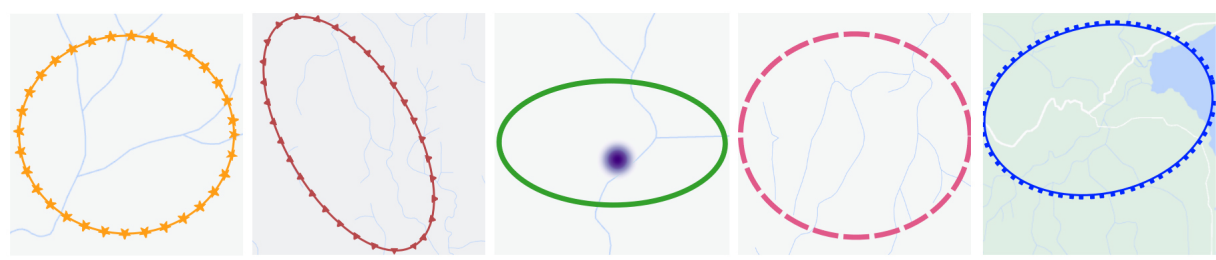

KNR

Kakenauwe
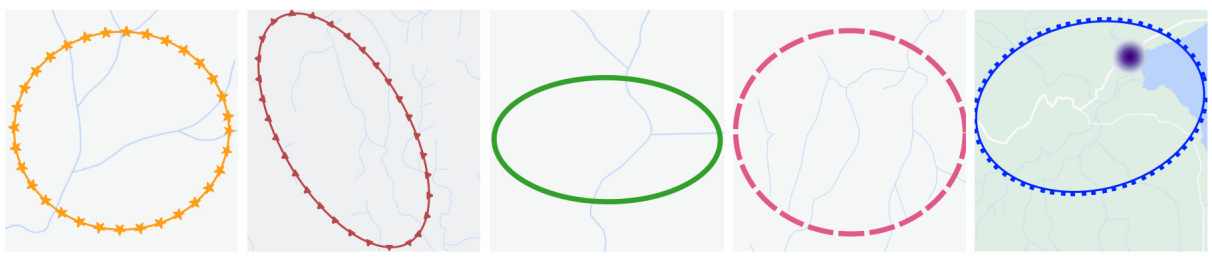

$0 \quad 250500 \mathrm{~m}$

M
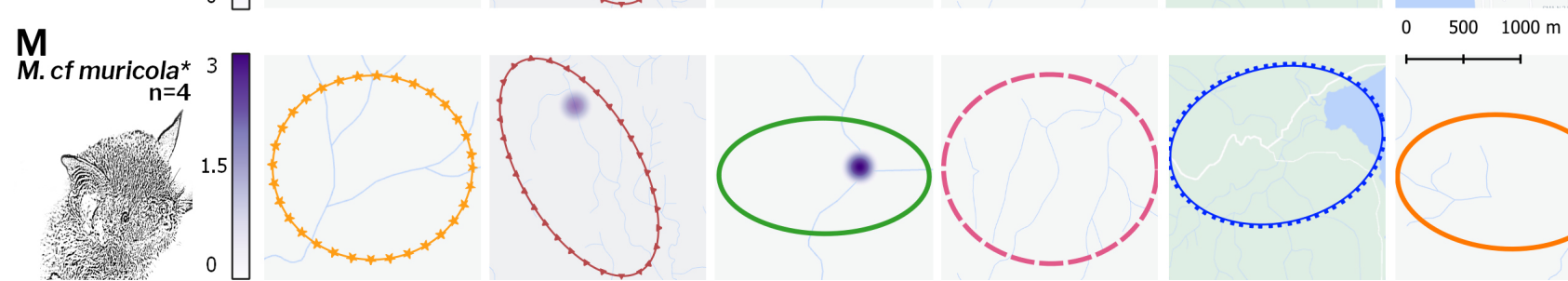

Fig. 3 - Continuation: The number of individuals for new species (species names and total number of captures/observations provided on $\mathrm{Y}$ axis) were counted at each trapping site located within survey localities (see Figure 1 for survey localities on Buton Island). Depth of colour is proportional to the number of individuals captured for each species at each trapping site and with detail listed in Table 2. Lines indicate survey locality boundaries (see Fig. 1 for further detail). Scale bars differ between columns. Map derived from Google Maps (2021). * Denotes photos provided by Sarah Curran.

These individuals were placed into the Leuconoe subfamily, with wing attachment being on the side of the foot just below the ankle. Upper premolars $\mathrm{P}^{2}$ and $\mathrm{P}^{3}$ were in line with the toothrow, with $\mathrm{P}^{3}$ being smaller than $\mathrm{P}^{2}$, corresponding with M. horsfieldii (Francis \& Hill 1998). Fur was dense, charcoal grey dorsally, and silver/ grey-white ventrally. Measurements of Buton individuals matched with Burgin et al. (2019) (Table 3). Currently, this species represents a complex and is in need of taxonomic revision (Burgin et al. 2019).

\section{Myotis c.f. moluccarum (Thomas 1915)}

Distribution for this species is scattered throughout Wallacea and New Guinea (Reardon \& Bonaccorso 2008). Individuals captured on Buton represent a minor range extension. Both $M$. c.f. moluccarum individuals were captured in coastal habitat at sea level.

One individual was incidentally found roosting on a ceiling c. $2.5 \mathrm{~m}$ off the ground in a hotel in Linsowu, while the other was caught in a mist-net near Labundo-bundo (Table 1 \& 2; Fig. 3L) trawling over a brackish river channel. This distribution suggests that this species is widespread across Buton.

Close examination of the hindfoot, metacarpals and forearm revealed measurements to be longer than that of M. c.f. horsfieldii (Table 3 \& 4). Upper premolars did not differ from $M$. c.f. horsfieldii, and wing attachment to side of the foot also placed them in the Leuconoe subfamily. Fur had more of a brown tinge, both dorsally and ventrally, compared to $M$. c.f. horsfieldii. None of the individuals showed signs of breeding. Taxonomy is still being resolved for this species, which has previously been included within Myotis adversus specimens and considered a part of the $M$. horsfieldii species group (Burgin et al. 2019).

\section{Myotis c.f. muricola (Gray 1846)}

A widespread species found across much of South and South-east Asia. This report represents a minor range 


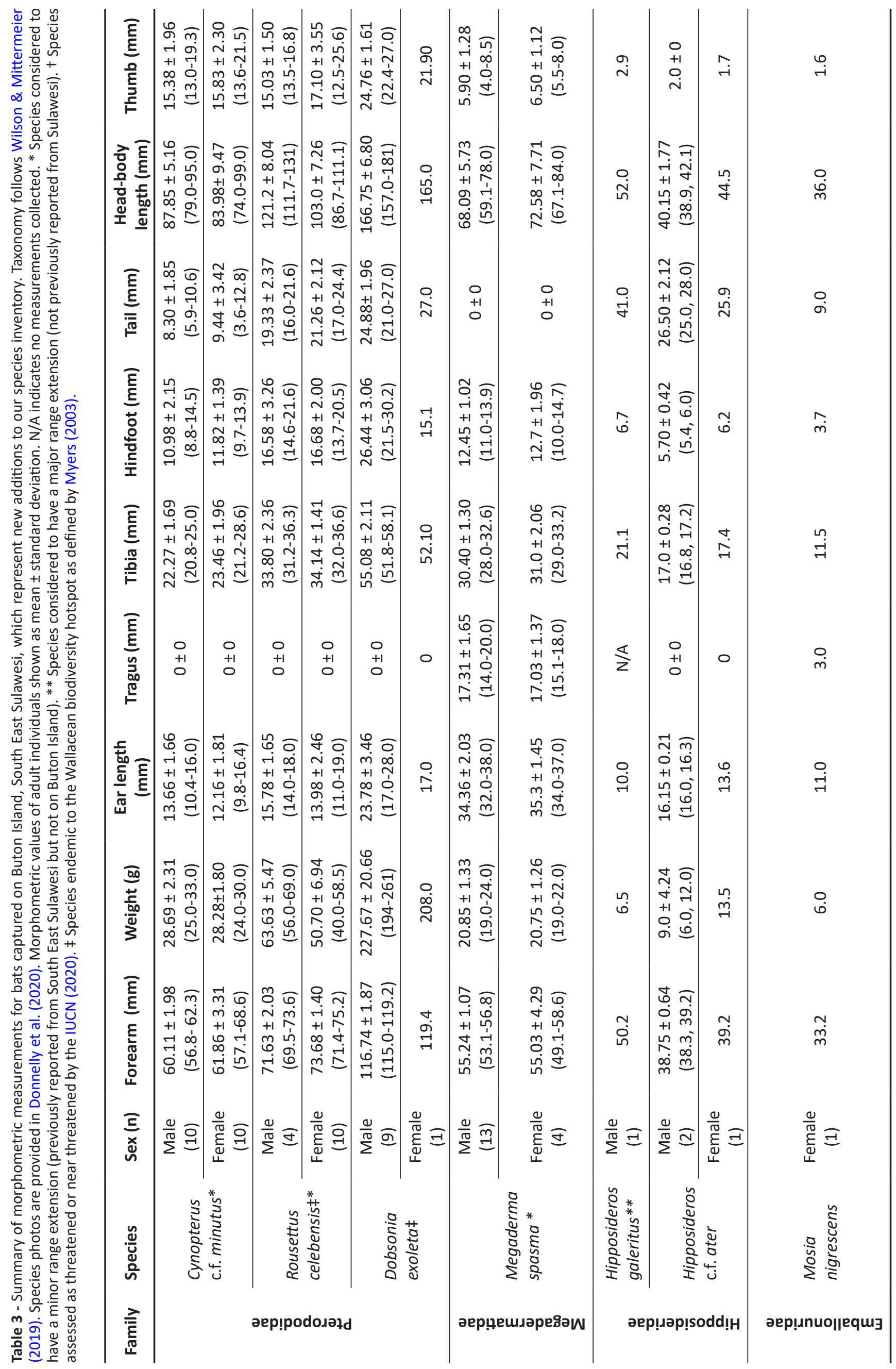




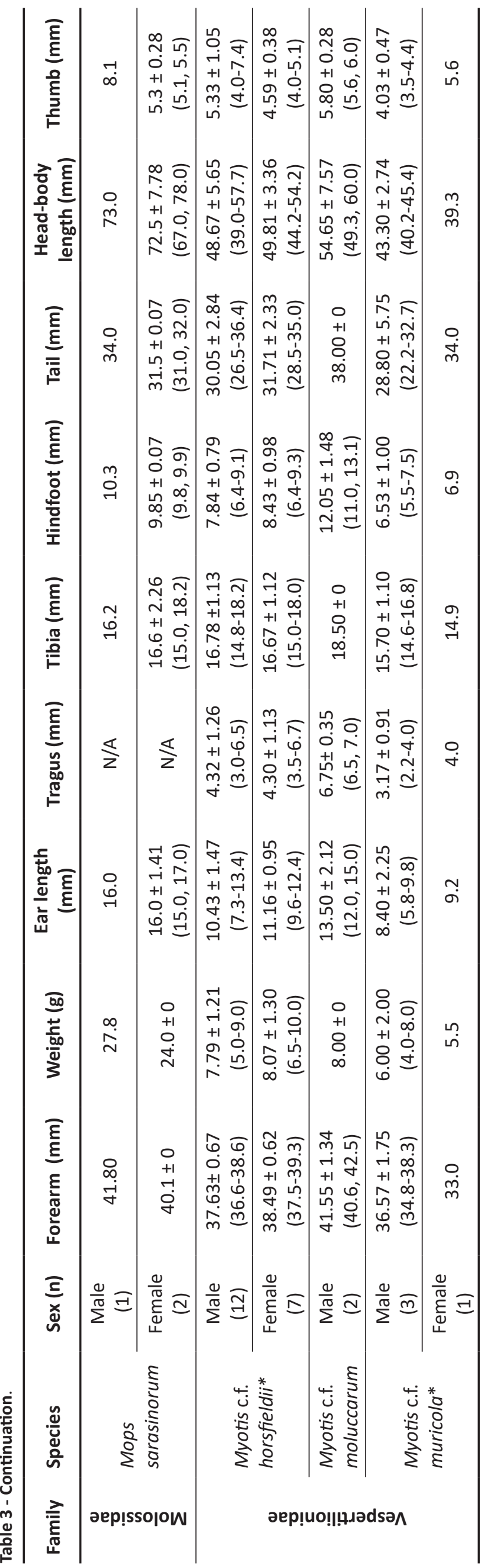

extension as it was previously reported occurring throughout mainland Sulawesi but not Buton (Srinivasulu \& Srinivasulu 2019).

Two individuals were caught in a harp trap positioned in dense forest adjacent to a river in Waculaea (Table 1 \& 2; Fig. 3M). The other individuals were both caught in mistnets: one in North Buton camp and the other within Lapago (Table 1 \& 2). Another individual was found roosting within a tightly rolled banana leaf, behaviour noted for $M$. muricola in Borneo (Phillipps \& Phillipps 2016). Only males showed signs of breeding, with enlarged testes.

These individuals can be separated from $M$. c.f. horsfieldii (see above) by their smaller size (see Table 3 \& 4) and wing attachment to the base of the toe, placing them in the Selysius subfamily (Francis \& Hill 1998). M. ater was ruled out as a potential identification due to the upper premolars of our individuals being in line with the toothrow, whereas in $M$. ater the second upper premolar is miniscule and intrudes inwards outside of the toothrow (Francis \& Hill 1998). Taxonomy for M. c.f. muricola on Sulawesi is still being resolved, with specimens being placed tentatively into the species M. browni (Burgin et al. 2019). It is possible that these individuals from Buton will also be reassigned to that species.

\section{DISCUSSION}

The results of our 2018 survey, in combination with Patterson et al. (2017), puts the total bat biodiversity of Buton Island at 35 species. This represents $46.7 \%$ of all Sulawesi's known bat diversity, based on the 75 species indicated to occur regionally (Wilson \& Mittermeier 2019), in c. 3\% of the region's land area, demonstrating the island's biodiversity and its status as an important conservation priority (Martin \& Blackburn 2010, Wiantoro et al. 2017). It is likely that further survey efforts on Buton will yield further species records. Current survey efforts have been largely directed towards lowland forest and adjacent habitats. Nonetheless, it is probable that more bat species occur within these habitats, and absence of species from current surveys here is not reflective of absence within lowland forest and adjacent habitats in general. More extensive surveys, including surveying at different times of year and within certain microhabitats (e.g. the forest canopy) may result in further new species detections (Wiantoro et al. 2017). Exploration of other habitat types (e.g. mangroves, small offshore islets, and urban areas) may also yield new species records, as noted for bat surveys in other underrepresented regions of Southeast Asia such as Borneo (Struebig et al. 2010). In addition, incorporating the use of different methodological approaches such as acoustic surveys may improve the Buton species inventory.

Our study highlights the need for further specimen and genetic material collection to resolve the taxonomic status, particularly for cryptic species, within the Cynopterus, Dobsonia, Myotis, Miniopterus, Kerivoula, and Rhinolophus genera. For example, discrepancies in morphological measurements (e.g. $2^{\text {nd }}$ metacarpal or forearm) may reveal a new species complex in Cynopterus or Kerivoula. Acoustic work may also help resolve differences within 


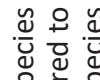

은 웡

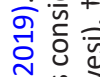

는

这

हn

寺安

$\infty$

둥웜

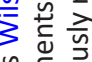

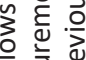

흥

हे है

응 응

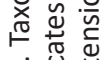

흐을

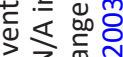

z

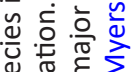

帘

흐은 웡

융 웅

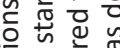

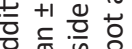

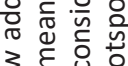

उ

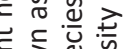

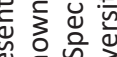

的*

는

등 후을

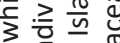

可

政

5

फั

山ै

亏을

o

元을

菏

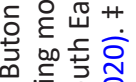

든

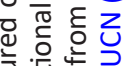

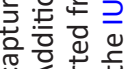

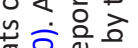

政

엄 긍

记

政

츠름

政

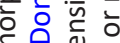

등

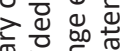

ह

흥형

ज语

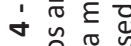

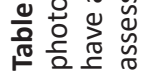

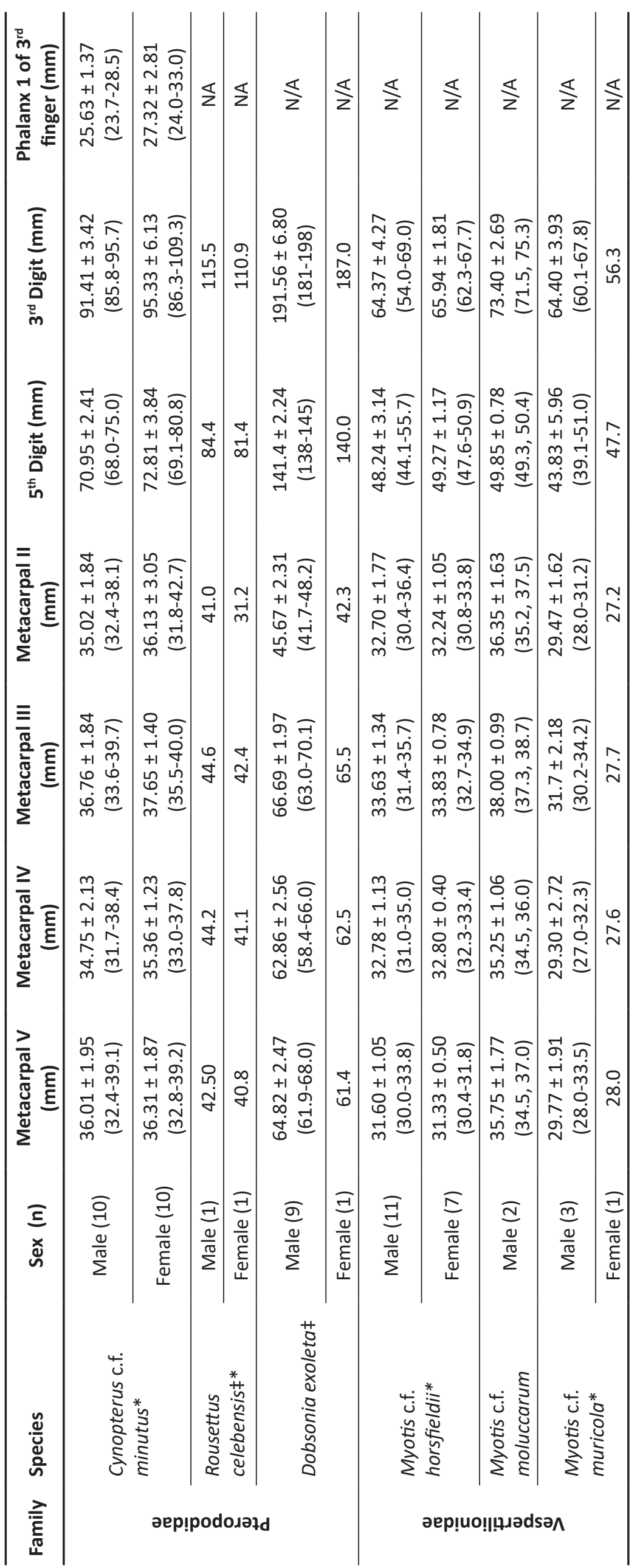




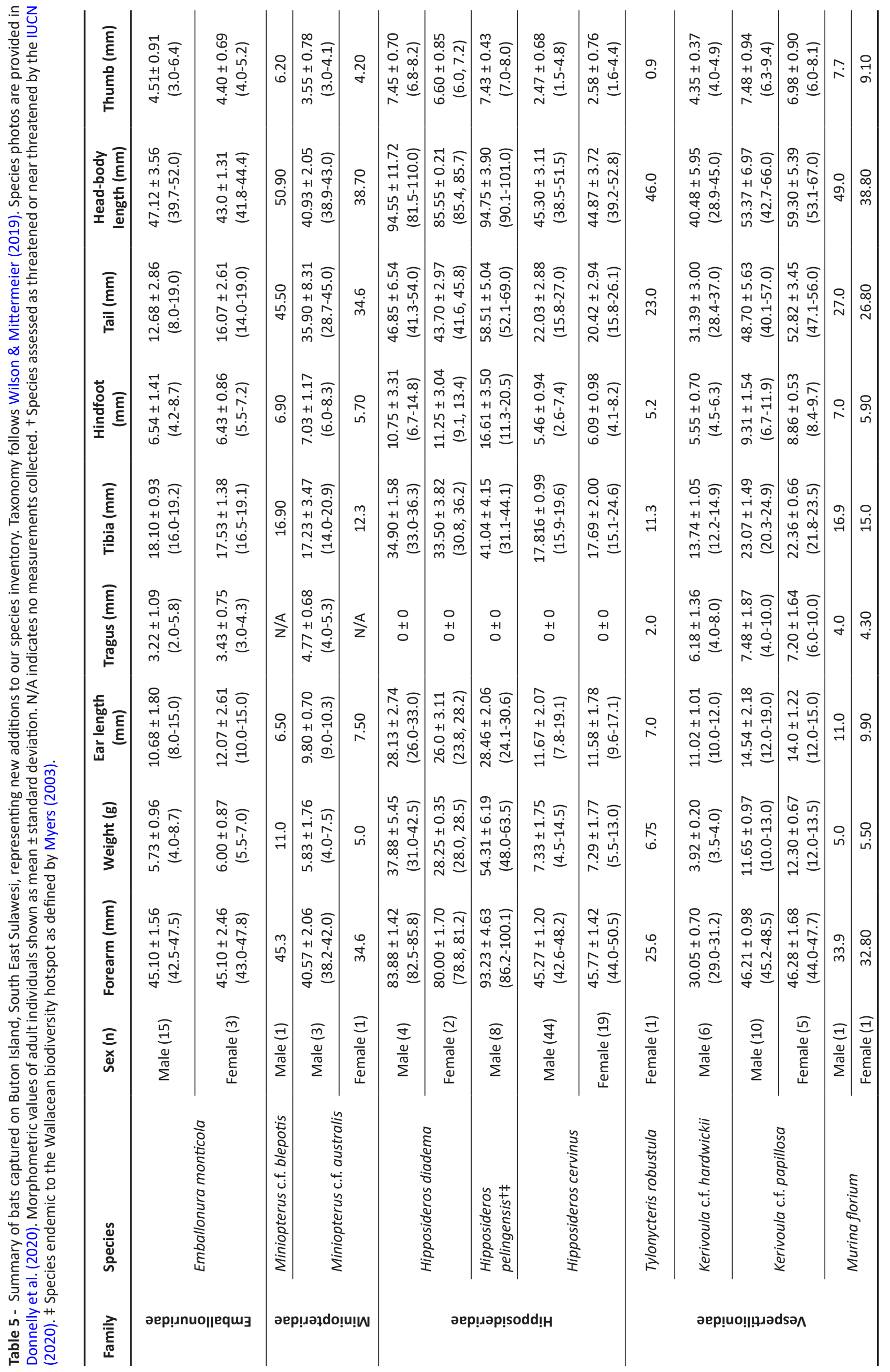




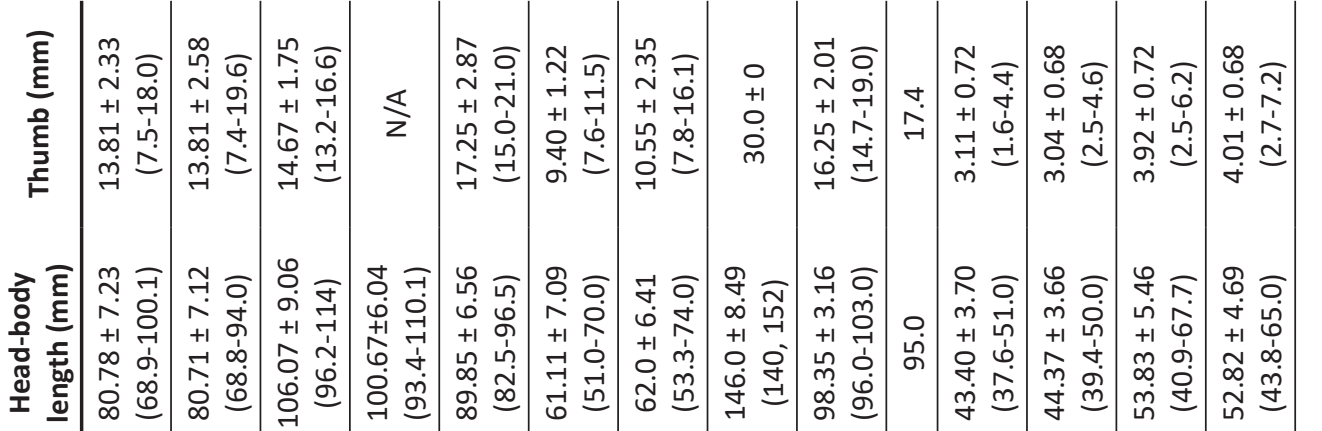

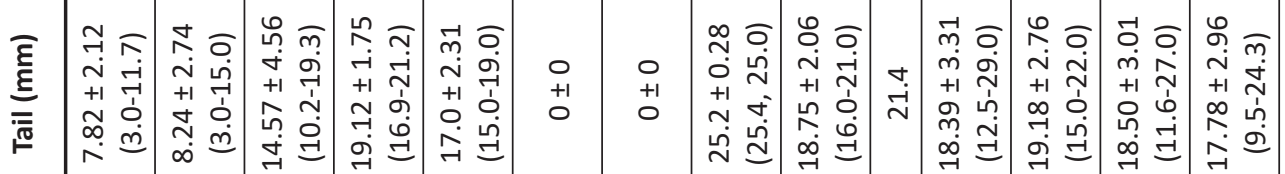

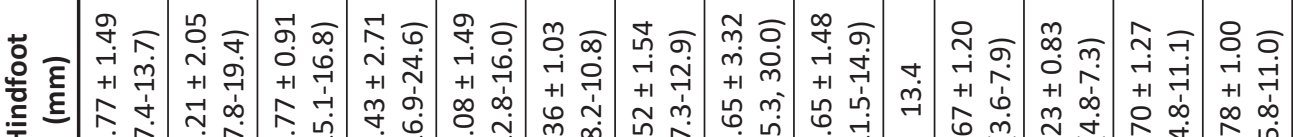

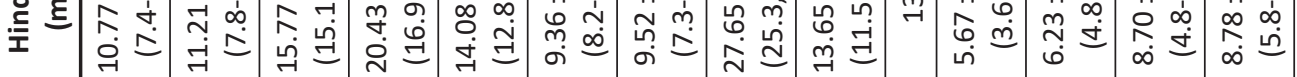

ह

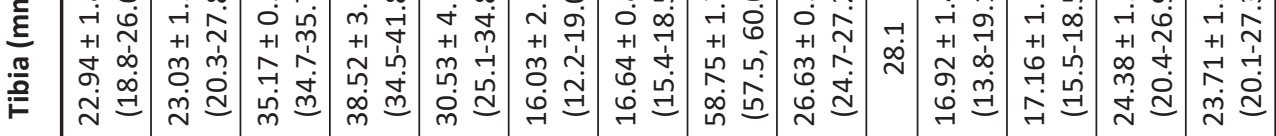

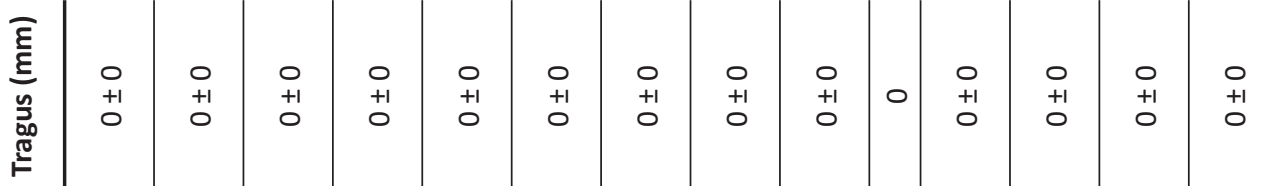

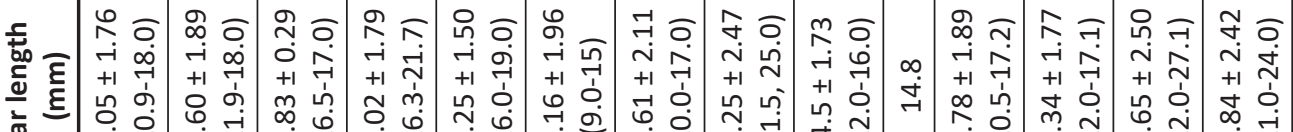

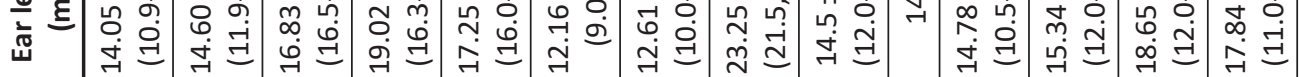

వol

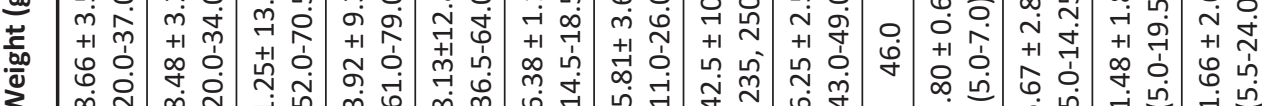
३l一

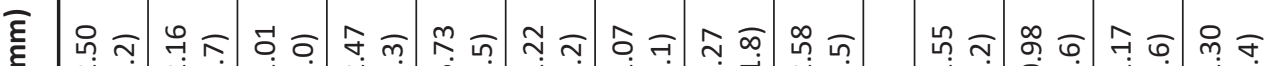

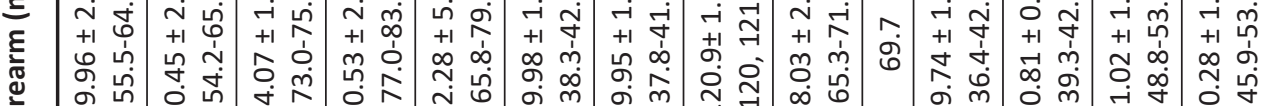
总

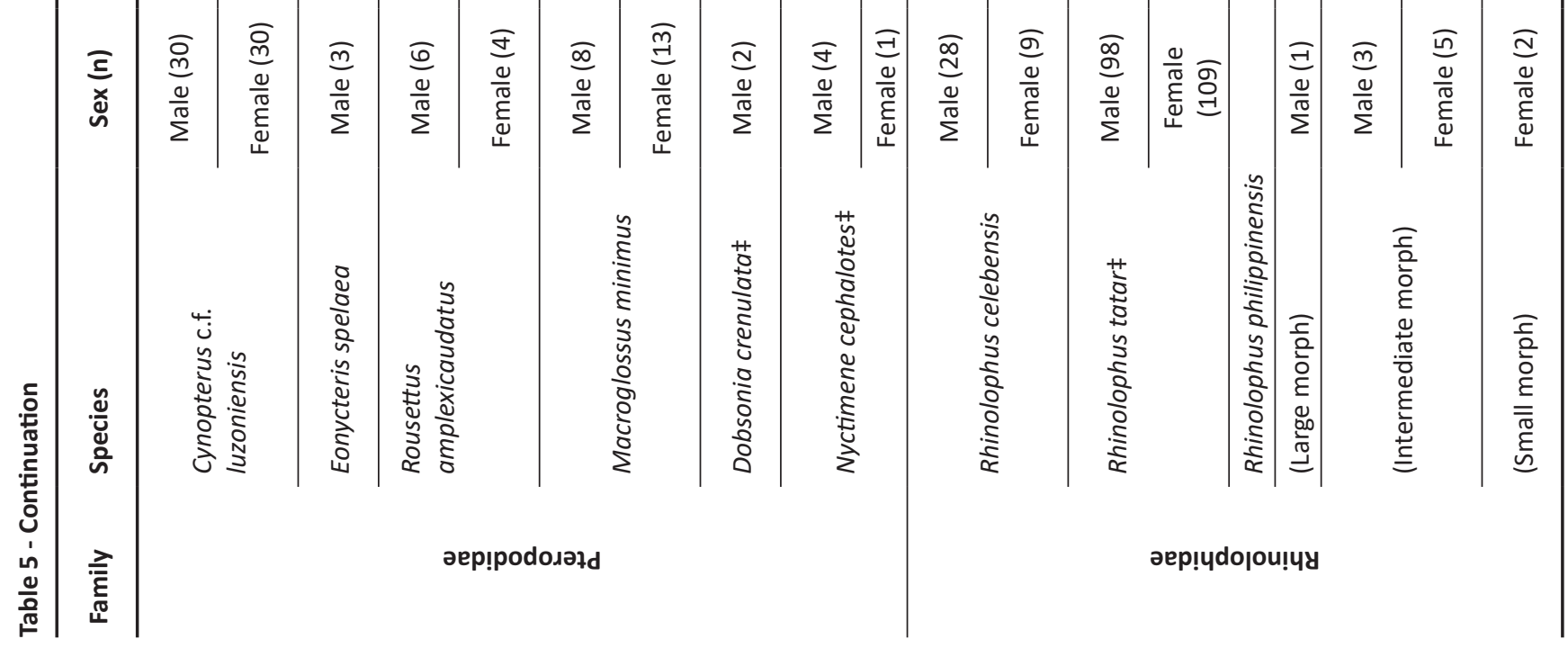

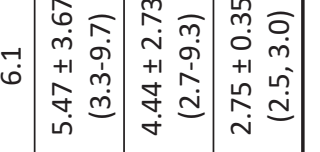

นกำ

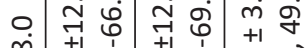

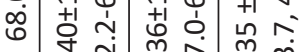

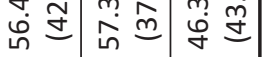

ㄷ. 0 우 0 o ๆ

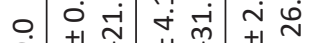

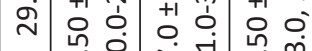

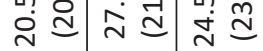

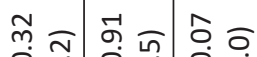

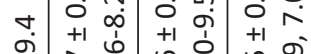

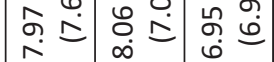

우중ํำ

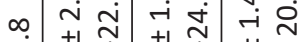

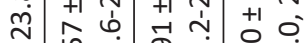

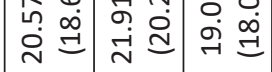
$\circ \quad \begin{array}{cccc}0 & 0 & 0 \\ +1 & +1 & +1 \\ 0 & 0 & 0\end{array}$ ก̊

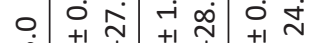

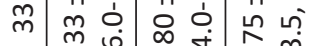

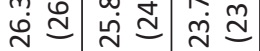

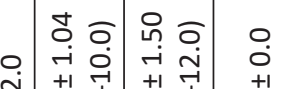

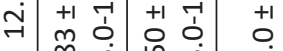

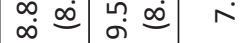

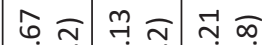

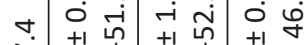

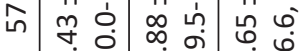

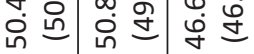

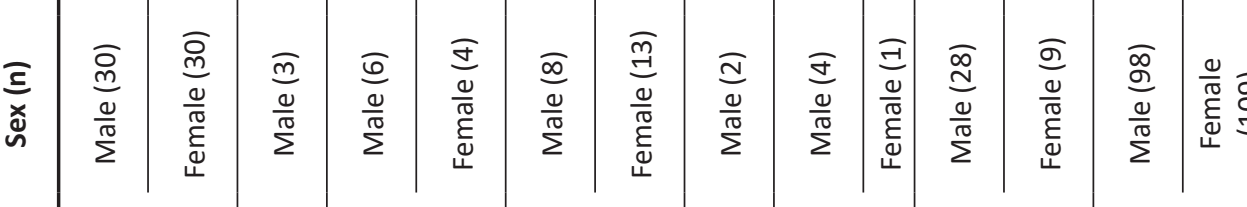

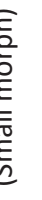




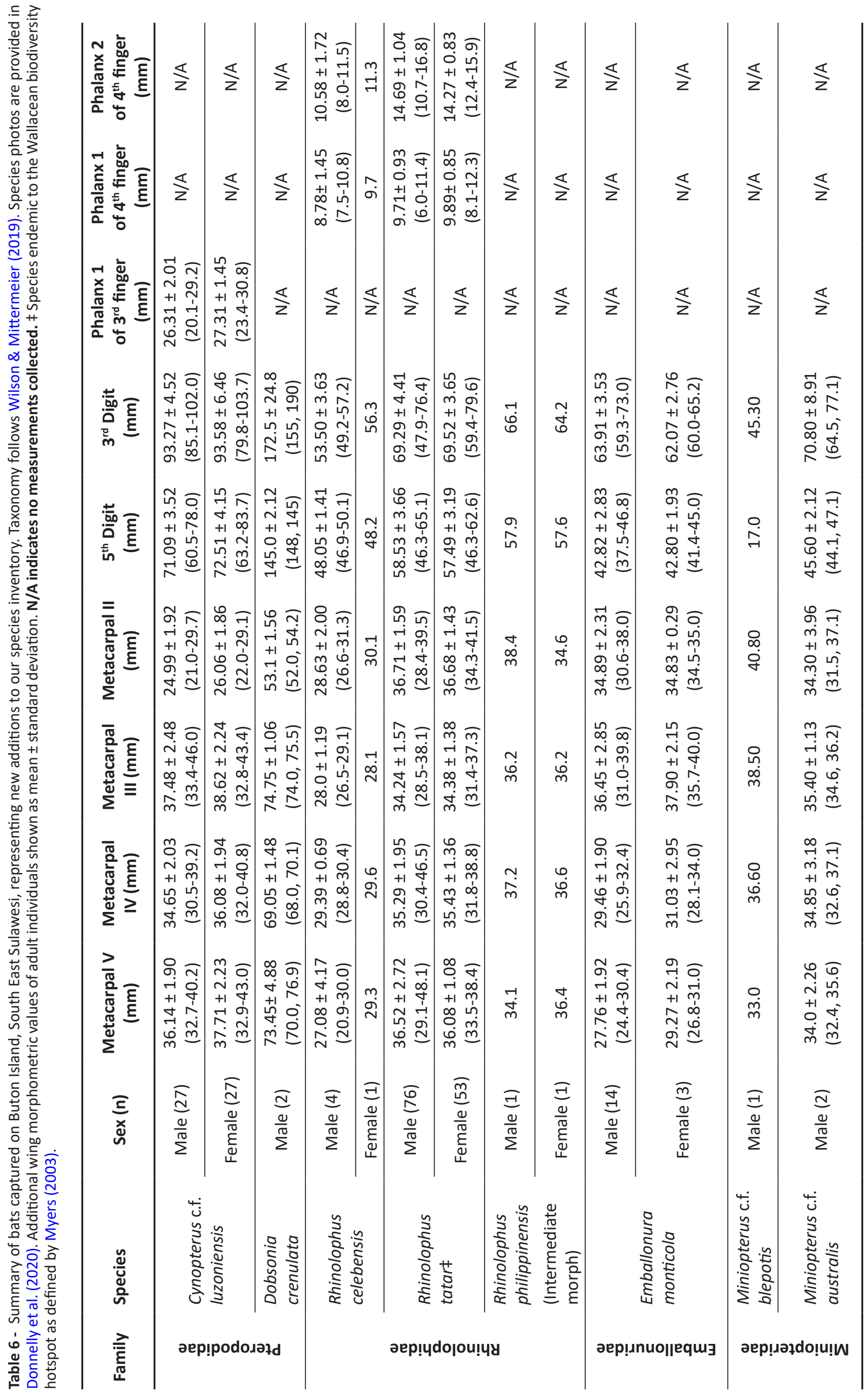




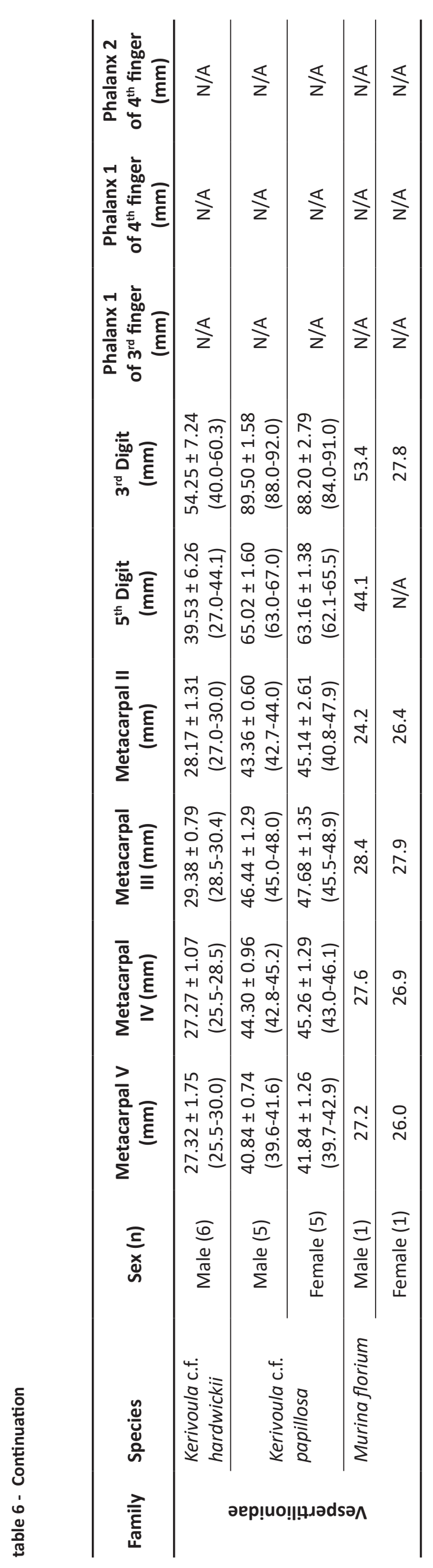

cryptic Rhinolophus and Hipposideros complexes. Resolving taxonomic status in these groups relies on pairing methodological approaches, for example genetic and acoustic analyses, to determine the source of variation between and within species (Kingston \& Rossiter 2004).

The Wallacea region remains, in general, poorly explored (Whitten et al. 2002), even in relation to adjacent parts of Southeast Asia such as Peninsular Malaysia. In addition, wildlife is increasingly sharing dwindling habitat with growing human populations in biodiversity hotspots (Williams 2013). Species in many taxa are still being described (O'Connell et al. 2019) and geographical distributions being extended for several taxa (Martin et al. 2018, Monkhouse et al. 2018). Despite their ecological importance, the diversity of bats and their respective geographic distributions are still poorly known, with many habitats and regions under-represented by limited surveys (Nunes et al. 2005, Patterson et al. 2017, Broto \& Mortelliti 2019). Here, we further demonstrate the need to expand knowledge of the biodiversity within the Wallacea region, including Sulawesi.

\section{ACKNOWLEDGEMENTS}

The authors acknowledge and are extremely grateful to all the Butonese collaborators for their traditional knowledge of the lowland rainforests, active involvement in research and engagement in conservation, and technical and logistical support allowing this conservation project to continue.

This project was supported by Universitas Halu Oleo and Operation Wallacea. The authors would like to express grateful thanks to our guides for their help in completing fieldwork, and the people of Labundo-bundo, Petetea, and Waodeburi villages for their hospitality. Special thanks go to Darwis, Fifin, and Idin. We thank M. Laidlaw, H. Voss, C. Cunningham, P. Fernandez-Fournier, B. Clark and S. Garvin for daily operations, research assistance and logistics. We would also like to personally thank S. Tsang, T. Kingston, J. Senawi, J. C-C. Huang, S. Rossiter, C. Francis, B. Lim, M. Stewart, L. Patrick, M. Struebig, S. Heinrichs, A. Freudmann, G. Binns, and S. Curran for assisting in identifications. To SEABCRU, the Hungarian Natural History Museum and the BIFA project for hosting our occurrence dataset. To $\mathrm{H}$. van Tol and C. Montauban for their assistance with analysis in $\mathrm{R}$ studio. We would also like to extend our gratitude to P.G. Akbar and $\mathrm{A}$. Chornelia for translating this paper into Bahasa alongside our authors. Finally, we thank A. López-Baucells, L. Torrent, and two anonymous reviewers for comments that significantly improved this manuscript.

Data collection was supported by Kementerian Riset dan Teknologi Republik Indonesia (RISTEK) under RISTEK permit no. 169/SIP/FRP/E5/Dit.KI/V/2018. 


\section{REFERENCES}

BATES, P. J. J., ROSSITER, S. J., SUYANTO, A. \& KINGSTON, T. (2007). A new species of Hipposideros (Chiroptera: Hipposideridae) from Sulawesi. Acta Chiropterol, 9(1): 13-26. https://doi.org/10.3161/150811007781694552

BERGMANS, W. \& ROZENDAAL, F. G. (1988). Notes On Collections Of Fruit Bats From Sulawesi And Some OffLying Islands (Mammalia, Megachiroptera). Zool. Verh, 248: 3-74.

BONACCORSO, F. J. (1998). Bats of Papua New Guinea. ed.: Conservation International. Washington D.C., USA, 489 pp.

BONACCORSO, F. J. \& LEARY, T. (2008). Mosia nigrescens. The IUCN Red List of Threatened Species 2008: e.T13904A4364016. https://doi.org/10.2305/IUCN. UK.2008.RLTS.T13904A4364016.enon 28/06/20

BONACCORSO, F. J. (2019). Family Emballonuridae (Sheathtailed Bats). In: Handbook of the Mammals of the World, vol. 9. Bats. ed.: Lynx Edicions. Barcelona, Spain, p.334373.

BROTO, B. \& MORTELLITI, A. (2019). The status of research on the mammals of Sulawesi, Indonesia. Mammal Rev, 49(1): 78-93. https://doi.org/10.1111/mam.12141

BURGIN, C. J., MORATELLI, R., CLÁUDIO, V. C., NOVAES, R. L. M., LÓPEZ-BAUCELLS, A. \& HASLAUER, R. (2019). Family Vespertilionidae (Vesper Bats). In: Handbook of the Mammals of the World, vol. 9. Bats. ed.: Lynx Edicions. Barcelona, Spain, p.716-981.

CAMPBELL, P., SCHNEIDER, C. J., ADNAN, A. M., ZUBAID, A. \& KUNZ, T. H. (2004). Phylogeny and phylogeography of Old World fruit bats in the Cynopterus brachyotis complex. Mol Phylogenet Evol, 33(3): 764-781. https:// doi.org/10.1016/j.ympev.2004.06.019

CSORBA, G., BUMRUNGSRI, S., FRANCIS, C., HELGEN, C., BATES, P., GUMAL, M., HEANEY, L., BALETE, D., ESSELSTYN, J., MCKENZIE, N., et al. (2008). Hipposideros ater. The IUCN Red List of Threatened Species 2008: e.T10111A3164225. https://doi.org//10.2305/IUCN. UK.2008.RLTS.T10111A3164225.en

DIETZ, C. \& VON HELVERSEN, O. (2004). Illustrated identification key to the bats of Europe. Electronic Publication. Version 1.0.

DONNELLY, M., SAMSUDIN, YUSTI, E., CURRAN, S., SMETHURST, R., CROPPER, O., FOX, C., PRYDE, M., VAN DER AAR, R. N., HAFIRUN, et al. (2020). Buton Island, South East Sulawesi, Indonesia. Bats of Buton Island. Chicago Field Museum, Chicago. https://fieldguides. fieldmuseum.org/guides/guide/940
DONNELLY, M., CORBEN, C., CURRAN, S., ARFIAN, A., SMETHURST, R., HAFIRUN, KARYA, A., ANALUDDIN, K., \& COURTNEY JONES, S.K. (2021). Bats of Buton Island SE Sulawesi 2018 Occurrence Dataset. Version 1.2. Southeast Asian Bat Conservation Research Unit. Occurrence dataset https://doi.org/10.15468/qnz3rs.

FLANNERY, T. F. (1995). Mammals of the South-West Pacific and Moluccan Islands. ed.: Cornell University Press. Ithaca, New York, USA, 464 pp.

FRANCIS, C. M. \& HILL, J. E. (1998). New records and a new species of Myotis (Chiroptera, Vespertilionidae) from Malaysia. Mammalia, 62(2): 241-252. https://doi. org/10.1515/mamm.1998.62.2.241

FRANCIS, C. M. (2019). Family Megadermatidae (FalseVampires). In: Handbook of the Mammals of the World, vol. 9. Bats. ed.: Lynx Edicions. Barcelona, Spain, p.182193.

GIANNINI, N. P., VAN CAKENBERGHE, V., BURGIN, C. J., TSANG, S. M., LAVERY, T. H., HINTSCHE, S., BONACCORSO, F. J., ALMEIDA, F. C. \& O'TOOLE, B. P. (2019). Family Pteropodidae (Old World Fruit Bats). In: Handbook of the Mammals of the World, vol. 9. Bats. ed.: Lynx Edicions. Barcelona, Spain, p.16-163.

GRAJAL, A. (1999). Biodiversity and the Nation State: Regulating Access to Genetic Resources Limits Biodiversity Research in Developing Countries. Conserv Biol, 13(1): 6-10.

GRAY, J.E. (1870). Catalogue of monkeys, lemurs, and fruit eating bats in the collection of the British Museum. British Museum (Natural History): London.

HAYES, J. P., OBER, H. K. \& SHERWIN, R. E. (2009). Survey and monitoring of bats. In: Ecological and Behavioral Methods for the Study of Bats, 2nd ed. ed.: The John Hopkins University Press. Baltimore, USA, p.168-175.

HUANG, J. C-C., JAZDZYK, E. L., NUSALAWO, M., MARYANTO, I., MAHARADATUNKAMSI, WIANTORO, S. \& KINGSTON, T. (2014). A recent bat survey reveals Bukit Barisan Selatan Landscape as a chiropteran diversity hotspot in Sumatra. Acta Chiropterol, 16(2): 413-449. https://doi. org/10.3161/150811014X687369

HUTSON, A. M., HELGEN, K., KINGSTON, T. \& SINAGA, U. (2019). Dobsonia exoleta. The IUCN Red List of Threatened Species 2019: e.T6775A22034230. https://doi. org/10.2305/IUCN.UK.2019-3.RLTS.T6775A22034230.en

IUCN. (2020). The IUCN Red List of Threatened Species, Version 2020.1. Accessed: 20/06/2020.

JENKINS, P. D. \& HILL, J. E. (1981). The status of Hipposideros galeritus Cantor, 1846 and Hipposideros cervinus (Gould, 1854) (Chiroptera: Hipposideridae). Bulletin of the British Museum (Natural History). Zoology, 41: 279-294. 
KINGSTON, T. \& ROSSITER, S. (2004). Harmonic-hopping in Wallacea's bats. Nature, 429: 654-657. https://doi. org/10.1038/nature02487

KINGSTON, T. (2013). Response of Bat Diversity to Forest Disturbance in Southeast Asia: Insights from Long-Term Research in Malaysia. In: Bat Evolution, Ecology, and Conservation. ed.: Springer. New York, USA, 169-185. https://doi.org/10.1007/978-1-4614-7397-8_9

KITCHENER, D. J. \& MAHARADATUNKAMSI. (1991). Description of a new species of Cynopterus (Chiroptera: Pteropodidae) from Nusa Tenggara, Indonesia. Rec. West. Aust. Mus., 15(2): 307-363.

KUNZ, T. H., HODGKISON, R. \& WEISE, C. D. (2009). Methods for capturing and handling bats. In: Ecological and behavioral methods for the study of bats. ed.: The Johns Hopkins University Press. Baltimore, Maryland, USA, p.335.

LIM, V. C., RAMLI, R., BHASSU, S. \& WILSON, J. J. (2017). A checklist of the bats of Peninsular Malaysia and progress towards a DNA barcode reference library. PLOS ONE, 12(7): e0179555. https://doi.org/10.1371/journal. pone.0179555

LIM, L-S., STRUEBIG, M. J., NOR ZALIPAH, M., MOHD-ADNAN, A., SENAWI, J., ZUBAID, A., MOHD SAH, S. A. \& ROSSITER, S. J. (2019). Bats from the understorey of lowland tropical rainforests across Peninsular Malaysia. JBRC, 12(1): 6882. https://doi.org/10.14709/BarbJ.12.1.2019.10

MARTIN, T. E. \& BLACKBURN, G. (2010). Impacts of Tropical Forest Disturbance Upon Avifauna on a Small Island with High Endemism: Implications for Conservation. Conserv Soc, 8(2): 127-139.

MARTIN, T. E., HARRISON, B. \& WHEELER, P. M. (2015). The Case for REDD+ Funding for the Forests of Buton Island, SE Sulawesi, Indonesia - A Summary. ed.: Operation Wallacea. Old Bolingbroke, United Kingdom.

MARTIN, T. E., MONKHOUSE, J., O'CONNELL, D. P., ANALUDDIN, K., KARYA, A., PRISTON, N. E. C., PALMER, C. A., HARRISON, B., BADDAMS, J., MUSTARI, A. H. et al. (2018). Distribution and status of threatened and endemic marsupials on the offshore islands of southeast Sulawesi, Indonesia. Aust Mammal, 41(1): 76-81. https://doi.org/10.1071/AM17052

MARYANTO, I., YANI, M., PRIJONO, S. N. \& WIANTORO, S. (2011). Altitudinal distribution of fruit bats (Pteropodidae) in Lore Lindu National Park, Central Sulawesi, Indonesia. Hystrix, 22(1): 167-177. https://doi. org/10.4404/hystrix-22.1-4480

MARYANTO, I., YANI, Y., PRIJONO, S. N. \& WIANTORO, S. (2012). A new species of fruit bat (Megachiroptera: Pteropodidae: Thoopterus) from Sulawesi and adjacent islands, Indonesia. Rec. West. Aust. Mus., 27(1): 68-84. https://doi.org/10.18195/issn.03123162.27(1).2012.068-08
MONKHOUSE, J. R., O'CONNELL, D. P., KELLY, D. J., ANALUDDIN, K., KARYA, A., MARPLES, N. M. \& MARTIN, T. E. (2018). The avifauna of Menui Island, south-east Sulawesi, Indonesia. Forktail, 34: 42-47.

MYERS, N., MITTERMEIER, R. A., MITTERMEIER, C. G., DA FONSECA, G. A. B. \& KENT, J. (2000). Biodiversity hotspots for conservation priorities. Nature, 403: 853858. https://doi.org/10.1038/35002501

MYERS, N. (2003). Biodiversity Hotspots Revisited. BioScience, 53(10): 916-917. https://doi. org/10.1641/0006-3568(2003)053[0916:BHR]2.0.CO;2

NESI, N., TSAGKOGEORGA, G., TSANG, S., NICOLAS, V., LALIS, A., SCANLON, A., RIESLE-SBARBARO, S., WIANTORO, S., HITCH, A., JUSTE, J., et al. (2021). Interrogating Phylogenetic Discordance Resolves Deep Splits in the Rapid Radiation of Old World Fruit Bats (Chiroptera: Pteropodidae). Syst Biol, 1-13. https://doi.org/10.1093/ sysbio/syab013

NUNES, A., MARQUES-AGUIAR, S., SALDANHA, N., SILVA, R. \& BEZERRA, A. (2005). New records on the geographic distribution of bat species in the Brazilian Amazonia. Mammalia, 69(1): 109-115. https://doi.org/10.1515/ mamm.2005.012

O'CONNELL, D. P., KELLY, D. J., LAWLESS, N., O'BRIEN, K., MARCAIGH, F. Ó., KARYA, A., ANALUDDIN, K. \& MARPLES, N. M. (2019). A sympatric pair of undescribed white-eye species (Aves: Zosteropidae: Zosterops) with different origins. Zool J Linn Soc-Lond, 186(3): 701-724. https:// doi.org/10.1093/zoolinnean/zlz022

PATTERSON, G., MARTIN, T. E., ADAMS, N., CROPPER, O., MUSTARI, A. H. \& TOSH, D. G. (2017). Lowland rainforest bat communities of Buton Island, South-east Sulawesi, including new regional records. Raffles B Zool, 65: 373385 .

PAYNE, J. \& FRANCIS, C. M. (2007). A Field Guide to the Mammals of Borneo. Revised edition. ed.: The Sabah Society. Kota Kinabalu, Malaysia, 332 pp.

PHELPS, K., ROSELL-AMBAL, R. G. B., TABARANZA, B., HEANEY, L., GONZALEZ, J. C., MOLUR, S. \& SRINIVASULU, C. (2019). Myotis horsfieldii. The IUCN Red List of Threatened Species 2019: e.T14166A22057415. https://doi. org/10.2305/IUCN.UK.2019-3.RLTS.T14166A22057415. en

PHILLIPPS, Q. \& PHILLIPPS, K. (2016). Phillipps' Field Guide to the Mammals of Borneo and Their Ecology: Sabah, Sarawak, Brunei, and Kalimantan. ed.: John Beaufoy Publishing Ltd. Oxford, United Kingdom, 400 pp.

REARDON, T. \& BONACCORSO, F. (2008). Myotis moluccarum. The IUCN Red List of Threatened Species 2008: e.T136770A4337745. https://doi.org/10.2305/ IUCN.UK.2008.RLTS.T136770A4337745.en 
REVILLIOD, P. (1911). Über einige Säugetiere von Celebes. Zool Anz, 37: 513-517.

RHEINDT, F. E., PRAWIRADILAGA, D. M., ASHARI, H., SUPARNO, GWEE, C. Y., LEE, G. W. X., WU, M. Y. \& NG, N. S. R. (2020). A lost world in Wallacea: Description of a montane archipelagic avifauna. Science, 367 (6474): 167170. https://doi.org/10.1126/science.aax2146

RILEY, J. (2002). Mammals on the Sangihe and Talaud Islands, Indonesia, and the impact of hunting and habitat loss. Oryx, 36(3): 288-296. https://doi.org/10.1017/ S0030605302000510

ROSELL-AMBAL, R. G. B., TABARANZA, B., MCKINNON, J., KINGSTON, T., MAHARADATUNKAMSI, D. \& WIANTORO, S. (2016). Mops sarasinorum. The IUCN Red List of Threatened Species 2016: e.T13847A22078424. https://doi.org/10.2305/IUCN.UK.2016-2.RLTS. T13847A22078424.en

ROSELL-AMBAL, G., KINGSTON, T. \& MARYANTO, I. (2019). Cynopterus luzoniensis. The IUCN Red List of Threatened Species 2019: e.T136798A22035092. https://doi. org/10.2305/IUCN.UK.2019-3.RLTS.T136798A22035092. en

RUEDAS, L., KINGSTON, T., HELGEN, K. \& SINAGA, J. (2008). Thoopterus nigrescens. The IUCN Red List of Threatened Species 2008: e.T21815A9321738. https://doi. org/10.2305/IUCN.UK.2008.RLTS.T21815A9321738.en

RUEDAS, L. \& SUYANTO, A. (2019). Cynopterus minutus. The IUCN Red List of Threatened Species 2019: e.T136423A21985433. https://doi.org/10.2305/IUCN. UK.2019-3.RLTS.T136423A21985433.en

SIMMONS, N. B. \& CIRRANELlO, A. L. (2020). Bat Species of the World: A taxonomic and geographic database. Accessed: 20/06/2020. https://batnames.org

SODHI, N. S. \& LIOW, L. H. (2000). Improving Conservation Biology Research in Southeast Asia. Conserv Biol, 14(4): 1211-1212. https://doi.org/10.1046/J.15231739.2000.99416.X

SOISOOK, P., TUNEU-CORRAL, C., MONADJEM, A. \& THONG, V. D. (2019). Family Hipposideridae (Old World LeafNosed Bats). In: Handbook of the Mammals of the World, vol. 9. Bats. ed.: Lynx Edicions. Barcelona, Spain, p.210-259.

SRINIVASULU, C., RACEY, P. A. \& MISTRY, S. (2010). A key to the bats (Mammalia: Chiroptera) of South Asia. J. Threat. Taxa, 2(7): 1001-1076. https://doi.org/10.11609/JoTT. 02352.1001-76

SRINIVASULU, B. \& SRINIVASULU, C. (2019). Hipposideros galeritus. The IUCN Red List of Threatened Species 2019: e.T10136A22090092. https://doi.org/10.2305/IUCN. UK.2019-3.RLTS.T10136A22090092.en
SRINIVASULU, B., SRINIVASULU, C. \& PHELPS, K. (2019). Megaderma spasma. The IUCN Red List of Threatened Species 2019: e.T12939A22022345. https://doi. org/10.2305/IUCN.UK.2019-2.RLTS.T12939A22022345. en

STRUEBIG, M. J., CHRISTY, L., PIO, D. \& MEIJAARD, E. (2010). Bats of Borneo: diversity, distributions and representation in protected areas. Biodivers Conserv, 19: 449-469. https://doi.org/10.1007/s10531-008-9482-5

SUYANTO, A. \& KARTIKASARI, S. N. (2001). Kelelawar di Indonesia (Bats of Indonesia). ed.: Puslitbang Biologi, LIPI. Bogor, Indonesia, $126 \mathrm{pp}$.

TAYLOR, P. J., LIM, B. K., PENNAY, M., SOISOOK, P., LOUREIRO, L. O., MORAS, L. M. \& KINGSTON, T. (2019). Family Molossidae (Free-tailed bats). In: Handbook of the Mammals of the World, vol. 9. Bats. ed.: Lynx Edicions. Barcelona, Spain, p.598-673.

TELNOV, D. (2011). Biodiversity, biogeography and nature conservation in Wallacea and New Guinea, vol. 1. ed.: The Entomological Society of Latvia. Riga, Latvia, 434 pp. https://doi.org/10.5962/bhl.title.150137

TSANG, S. M. (2016). Cynopterus titthaecheilus. The IUCN Red List of Threatened Species 2016: e.T6107A22114054. https://doi.org/10.2305/IUCN.UK.2016-2.RLTS. T6107A22114054.en

TSANG, S. M. \& SHEHERAZADE. (2016). Acerodon celebensis. The IUCN Red List of Threatened Species 2016: e.t137A21988719. https://doi.org//10.2305/ IUCN.UK.2016-2.RLTS.T137A21988719.en

WANG, X. \& MÜLLER, R. (2009). Pinna-rim skin folds narrow the sonar beam in the lesser false vampire bat (Megaderma spasma). J. Acoust. Soc. Am., 126(6): 33113318 https://doi.org/10.1121/1.3257210

WHITTEN, T., MUSTAFA, M. \& HENDERSON, G. S. (2002). The Ecology of Sulawesi. 2nd Edition. ed.: Gadjah Mada University Press. Yogyakarta, Java, Indonesia, 754 pp.

WIANTORO, S., HITCH, A. T., ENGILIS, I. E., GUNAWAN, H. \& ENGILIS, A. (2017). Bats (Chiroptera) recorded in the lowland of Southeast Sulawesi, Indonesia with notes on taxonomic status and significant range extensions. Mammalia, 81(4): 385-400. https://doi.org/10.1515/ mammalia-2015-0153

WILLIAMS, J. N. (2013). Humans and biodiversity: population and demographic trends in the hotspots. Popul Environ, 34: 510-523. https://doi.org/10.1007/s11111-012-01753

WILSON, D. E. \& MITTERMEIER R. A. (2019). Handbook of the Mammals of the World, vol. 9. Bats. ed.: Lynx Edicions. Barcelona, Spain, 1008 pp. 